\title{
Chapter 5 \\ Attribution: How Is It Relevant for Loss and Damage Policy and Practice?
}

\author{
Rachel A. James, Richard G. Jones, Emily Boyd, Hannah R. Young, \\ Friederike E. L. Otto, Christian Huggel and Jan S. Fuglestvedt
}

\begin{abstract}
Attribution has become a recurring issue in discussions about Loss and Damage (L\&D). In this highly-politicised context, attribution is often associated with responsibility and blame; and linked to debates about liability and compensation. The aim of attribution science, however, is not to establish responsibility, but to further scientific understanding of causal links between elements of the Earth System and society. This research into causality could inform the management of climate-related risks through improved understanding of drivers of relevant hazards, or, more widely, vulnerability and exposure; with potential benefits regardless of political positions on L\&D. Experience shows that it is nevertheless difficult to have open discussions about the science in the policy sphere. This is not only a missed opportunity, but also problematic in that it could inhibit understanding of scientific results and uncertainties, potentially leading to policy planning which does not have sufficient scientific
\end{abstract}

R. A. James $(\varangle) \cdot$ F. E. L. Otto

Environmental Change Institute, University of Oxford, Oxford, UK

e-mail: rachel.james@eci.ox.ac.uk

E. Boyd

LUCSUS, Lund University, Lund, Sweden

C. Huggel

Department of Geography, University of Zurich, Zurich, Switzerland

J. S. Fuglestvedt

CICERO, Oslo, Norway

R. A. James

Department of Oceanography, University of Cape Town, Cape Town, South Africa

R. G. Jones

School of Geography and the Environment, University of Oxford, Oxford, UK

R. G. Jones

Met Office Hadley Centre, Exeter, UK

E. Boyd

Department of Geography, University of Reading, Reading, UK

H. R. Young

Department of Meteorology, University of Reading, Reading, UK

(C) The Author(s) 2019

R. Mechler et al. (eds.), Loss and Damage from Climate Change, Climate Risk

Management, Policy and Governance, https://doi.org/10.1007/978-3-319-72026-5_5 
evidence to support it. In this chapter, we first explore this dilemma for sciencepolicy dialogue, summarising several years of research into stakeholder perspectives of attribution in the context of L\&D. We then aim to provide clarity about the scientific research available, through an overview of research which might contribute evidence about the causal connections between anthropogenic climate change and losses and damages, including climate science, but also other fields which examine other drivers of hazard, exposure, and vulnerability. Finally, we explore potential applications of attribution research, suggesting that an integrated and nuanced approach has potential to inform planning to avert, minimise and address losses and damages. The key messages are

- In the political context of climate negotiations, questions about whether losses and damages can be attributed to anthropogenic climate change are often linked to issues of responsibility, blame, and liability.

- Attribution science does not aim to establish responsibility or blame, but rather to investigate drivers of change.

- Attribution science is advancing rapidly, and has potential to increase understanding of how climate variability and change is influencing slow onset and extreme weather events, and how this interacts with other drivers of risk, including socioeconomic drivers, to influence losses and damages.

- Over time, some uncertainties in the science will be reduced, as the anthropogenic climate change signal becomes stronger, and understanding of climate variability and change develops.

- However, some uncertainties will not be eliminated. Uncertainty is common in science, and does not prevent useful applications in policy, but might determine which applications are appropriate. It is important to highlight that in attribution studies, the strength of evidence varies substantially between different kinds of slow onset and extreme weather events, and between regions. Policy-makers should not expect the later emergence of conclusive evidence about the influence of climate variability and change on specific incidences of losses and damages; and, in particular, should not expect the strength of evidence to be equal between events, and between countries.

- Rather than waiting for further confidence in attribution studies, there is potential to start working now to integrate science into policy and practice, to help understand and tackle drivers of losses and damages, informing prevention, recovery, rehabilitation, and transformation.

Keywords Loss and Damage $\cdot$ Attribution $\cdot$ Climate change $\cdot$ Science-policy interface 


\subsection{Introduction}

The science of attributing observed phenomena to human-induced and natural climate drivers has seen remarkable progress since its emergence in the 1990s. The first studies demonstrated that the late 20th century increase in global mean surface temperature would not have occurred without human influence on concentrations of greenhouse gases (GHGs) and aerosols (Tett et al. 1999; Stott et al. 2000). In subsequent years, many more studies of global temperature supported this finding, leading to greater and greater confidence in anthropogenic influence on global warming (Santer et al. 1995; Mitchell et al. 2001; Hegerl et al. 2007; Bindoff et al. 2013), and, the most recent report of the Intergovernmental Panel on Climate Change (IPCC) states that anthropogenic drivers are "extremely likely [or $>95 \%$ probability] to have been the dominant cause of the observed warming since the mid-20th century" (IPCC 2014). These scientific attribution statements provide a fundamental underpinning for the United Nations Framework Convention on Climate Change (UNFCCC; UN 1992), demonstrating that recent warming was predominantly caused by human emissions of carbon dioxide, methane, and short-lived climate forcings (SLCFs), and modifications to GHG concentrations associated with land use change (LUC); and thus establishing the imperative for mitigation.

As the UNFCCC's mandate has extended beyond mitigation, to include adaptation, and now Loss and Damage (L\&D) from climate change impacts (UNFCCC 2013, 2015; see introductory chapter by Mechler et al. 2018), new challenges and questions are emerging about the science of attribution, and its role in policy. Whilst there is strong evidence from attribution studies that human activity is influencing global and regional temperatures (Bindoff et al. 2013), and also other global and regional scale changes (including sea level rise, e.g. Church et al. 2013; and atmospheric moisture content, e.g. Santer et al. 2007), understanding how anthropogenic drivers influence losses and damages in particular ecosystems, economies, and communities is a very different endeavour, which raises questions extending far beyond physical climate science. When referring to the loss of coastline from a storm surge, fatalities during a heat wave, or famine during a drought, the issue of causality becomes more challenging scientifically. As we will explore in this chapter, at this scale and complexity, multiple factors contribute to a specific loss or damage, and the signal from climate change is more difficult to detect relative to the many other potential influences on hazard occurrence, exposure, and vulnerability (Huggel et al. 2013).

Questions about attribution of specific losses and damages also make the implications of the scientific research more political than the implications of studies into global or regional climate. Now questions are being asked about the influence of human actions (through anthropogenic GHGs) on specific people, and often not the same people who were responsible for the majority of GHG emissions. It is therefore not difficult to understand why, in the context of L\&D policy discussions, attribution has often been associated with responsibility, blame, and liability. For scientists, research into causality is a fundamental route towards understanding how the Earth System works, and attribution research is not necessarily intended to identify responsible parties. In the context of political negotiations, however, even mentioning attribution science can be seen as, and arguably often is, a political move. 
If attribution science is to be helpful in this controversial policy space, scientists must not only push the boundaries of their physical scientific analyses, but also improve their understanding of policy mechanisms, and the motivations, perceptions, and knowledge of policy-makers and practitioners. Interdisciplinary research in collaboration with social scientists, and transdisciplinary studies with stakeholders in policy and practice, are fundamental to identify whether there are entry points for physical attribution science. In response to this need, the authors have been investigating the potential relevance of attribution science for L\&D by attending UNFCCC meetings (James et al. 2014a; Parker et al. 2015; Otto et al. 2015a), interviewing stakeholders about attribution (Parker et al. 2017a), playing participatory games about attribution science and its role in L\&D (Parker et al. 2016), and more broadly analysing perspectives of what L\&D signifies (Boyd et al. 2017). This research has highlighted the challenge of applying attribution science in a context where it is difficult to even discuss climate change science (James et al. 2014a). There are many vested interests in the outcomes of attribution research, and, for negotiators of climate policy, clarity on exactly what can and cannot be attributed might not be considered helpful.

Unsurprisingly, then, our research also suggests that stakeholders to the L\&D debate have quite different understandings of what can and cannot be attributed to anthropogenic climate change (Parker et al. 2017a). Yet, we find that attribution is an issue which recurs in negotiations: and there is a risk that, without improved understanding, policy planning could proceed based on assumptions about the science, and then later find that the evidence available is either stronger or weaker than expected. In this chapter, we revisit the question of whether and how attribution science might be useful for L\&D policy and practice, first examining existing understandings of attribution in L\&D policy discussions, then outlining the science itself and what it can offer, and finally turning to potential applications. We hope to open up opportunities for more informed dialogue between researchers, policy-makers, and practitioners: helping scientists to understand the L\&D policy context, the perceptions and implications of attribution, helping policy-makers and practitioners to understand what the science can offer, and identifying areas which might require further integration for progress (see Box 5.1 for key messages). 


\section{Box 5.1 Key Messages}

- In the political context of climate negotiations, questions about whether losses and damages can be attributed to anthropogenic climate change are often linked to issues of responsibility, blame, and liability.

- Attribution science does not aim to establish responsibility or blame, but rather to investigate drivers of change.

- Attribution science is advancing rapidly, and has potential to increase understanding of how climate variability and change is influencing slow onset and extreme weather events, and how this interacts with other drivers of risk, including socio-economic drivers, to influence losses and damages.

- Over time, some uncertainties in the science will be reduced, as the anthropogenic climate change signal becomes stronger, and understanding of climate variability and change develops.

- However, some uncertainties will not be eliminated. Uncertainty is common in science, and does not prevent useful applications in policy, but might determine which applications are appropriate. It is important to highlight that in attribution studies, the strength of evidence varies substantially between different kinds of slow onset and extreme weather events, and between regions. Policy-makers should not expect the later emergence of conclusive evidence about the influence of climate variability and change on specific incidences of losses and damages; and, in particular, should not expect the strength of evidence to be equal between events, and between countries.

- Rather than waiting for further confidence in attribution studies, there is potential to start working now to integrate science into policy and practice, to help understand and tackle drivers of losses and damages, informing prevention, recovery, rehabilitation, and transformation.

Section 5.2 summarises findings from our transdisciplinary research of perspectives on attribution in L\&D policy discussions, drawing directly on qualitative evidence from stakeholder interviews (see Box 5.2). Section 5.3 then provides an overview of sources of evidence about attribution of L\&D to climate variability and anthropogenic climate change. This is not restricted to physical climate science, but also includes other fields of enquiry which investigate causative links between L\&D, climate and weather, and human activity. Section 5.4 will discuss if and how such attribution science might be applied to support L\&D policy and practice, taking into account previous ideas from the L\&D literature, and stakeholder interviews (see 5.2), but also drawing on our own conclusions and ideas about potentially fruitful applications. 


\section{Box 5.2 Evidence from stakeholder interviews}

The discussion of perspectives of attribution in the context of L\&D policy in this chapter draws on qualitative evidence from two research projects which included interviews with stakeholders to L\&D discussions. The first project aimed to explore stakeholders' understandings of probabilistic event attribution in relation to L\&D (Parker et al. 2017a), and the second project was designed to more broadly investigate stakeholder perspectives on L\&D (Boyd et al. 2017). In both projects we asked stakeholders what kind of scientific evidence might be relevant for L\&D policy, and how; and both projects led to insights into stakeholder perspectives on attribution science, including some consistent findings. The methodologies are described more thoroughly in the key academic papers, but here we provide a brief overview of the interview design and participants to provide context for the quotations that are included in this chapter. All interview data were anonymised and analysed for the respective papers, and here we draw on key quotations which emerged from these analyses.

The focus of the Parker et al. (2017a) study was on just one area of attribution research: probabilistic event attribution (PEA), a rapidly emerging field which aims to explore the extent to which anthropogenic emissions influence the likelihood and magnitude of specific extreme weather events such as heatwaves, floods and droughts in a specific location (see Sect. 5.3). Qualitative, semi-structured interviews were conducted between November 2013 and July 2014 with 31 stakeholders including UNFCCC delegates, representatives from non-governmental organisations, climate scientists, and social scientists. Interview questions focusing on the extent to which the interviewees understood PEA, and their views about its relevance to L\&D policy.

The broader study of stakeholder perspectives on L\&D, described in Boyd et al. (2017), was prompted by the authors' work on the relevance of attribution science for L\&D policy (including Parker et al. 2017a). One of the emerging insights from the initial engagement with $L \& D$ discussions was the difficulty of initiating detailed discussions about science and practice to understand and address L\&D, given the controversy of the topic, but also the lack of clarity on the concept of L\&D (James et al. 2014a). This prompted an in-depth investigation of stakeholder perspectives of $L \& D$, in which interviewees were asked how they would define $L \& D$, the relationship between $L \& D$ and adaptation, and what actions might be needed to address L\&D. On the basis of these interviews a diverse spectrum of ideas about L\&D was identified, characterised as a typology of four perspectives (see Fig. 5.1). The interviews included questions about the relevance of anthropogenic climate change in the context of L\&D and what kind of science might be needed for L\&D policy, and it is these aspects which we discuss in this chapter. 36 qualitative, semi-structured interviews were conducted between April and November 2015 with stakeholders from science, policy, and practice, including negotiators, adaptation and disaster risk practitioners, and researchers with expertise in climate science, social science, law, philosophy, and economics. 


\subsection{Attribution in the Context of L\&D: Why Is Attribution a Critical Issue?}

\subsubsection{Recurring Questions: Is This Really About Anthropogenic Climate Change?}

The UNFCCC has a mandate to address anthropogenic climate change (UN 1992). Its ultimate objective is to "achieve stabilization of greenhouse gas concentrations in the atmosphere at a level that would prevent dangerous anthropogenic interference with the climate system" (UN 1992:4), and therefore the original focus of UNFCCC discussions was on mitigation, or reducing GHGs. However, there has long been a recognition that some climate change impacts cannot be avoided (e.g. Meehl 2005; Wigley 2005); and the UNFCCC now has frameworks and mechanisms to address climate change impacts in terms of adaptation (UNFCCC 2011) and more recently L\&D (UNFCCC 2013, 2015; see also introductory chapter by Mechler et al. 2018).

In seeking to address the impacts of anthropogenic climate change, the boundaries of the UNFCCC's mandate become less clear. Efforts to help people cope with climate change include risk reduction, e.g. by reducing vulnerability or more generally by enhancing adaptive capacity, and improving disaster response and recovery. These activities are already important ambitions for institutions which focus on development, disaster risk management, and humanitarian aid. An obvious question is therefore: what is distinct about adaptation and/or L\&D? How should the UNFCCC interact with UNDP (the UN Development Programme), UNISDR (the UN Office for Disaster Risk Reduction), and a whole host of other UN agencies and international organisations? Which activities are specific to climate change ${ }^{1}$ In the case of L\&D, the term- "losses and damages"- - has been used in disaster risk reduction for many years. ${ }^{2}$ Losses and damages from natural disasters have occurred and would continue to occur without climate change. So, which losses and damages are relevant for the UNFCCC? What further effort is needed to address the new and/or additional losses and damages which will result from climate change?

These questions about institutional mandates and responsibilities lead to questions about attribution: about which losses and damages can be attributed to anthropogenic climate change. It is not easy to find conclusive scientific answers, partly because these attribution questions are motivated and posed differently to research questions in scientific studies (Otto et al. 2016), and partly due to the complexity of isolat-

\footnotetext{
${ }^{1}$ Similar questions were raised by many of the stakeholders we interviewed (see Box 5.2), for example one said: "That's a fundamental question—am I fighting climate change or poverty?", and one interviewee described the challenge in UNFCCC L\&D discussions to "draw the distinction about what's considered adaptation and L\&D, and some of the humanitarian and DRR issues", explaining "we had a very long discussion in the committee meeting just to discuss whether the humanitarian assistance can be counted for climate finance".

${ }^{2}$ As one interviewee highlighted (see Box 5.2), the "use of this phrase in this very policy context is very different from use of the phrase in the disaster risk management community, where they're looking at L\&D from all events".
} 
ing the influence of anthropogenic climate change on specific losses and damages. Scientific attribution studies usually take anthropogenic emissions as their starting point, and ask what influence those emissions have had on climate and weather. In policy discussions, attribution questions emerge from questions of how to address specific cases of losses and damages, and what proportion of the losses or damages can be related to anthropogenic climate change. As we will outline in Sect. 5.3, at a local scale it becomes more challenging to understand how the influence of anthropogenic climate change interacts with natural variability in weather and climate. Furthermore, the influence of hazards resulting from local climate changes and extreme weather events on people (through impacts on health, water resources, food systems, infrastructure and beyond) interacts with a whole range of other drivers. These include the vulnerability and exposure components of coupled human-natural systems (see chapters by Bouwer 2018; Lopez et al. 2018 and Botzen et al. 2018). These complexities and uncertainties perhaps start to explain why questions about attribution recur in UNFCCC negotiations ${ }^{3}$ : there are obvious and practical reasons to ask which L\&D is related to climate change, but no straightforward answers.

\subsubsection{Questions with Political Implications: Controversy and Ambiguity in the Negotiations}

The answers to attribution questions also have important political implications. Attributing specific losses and damages to GHG emissions might imply responsibility for emitters (potentially including countries, regions, sectors, companies, and individuals). Some of the stakeholders we interviewed (see Box 5.2) highlighted that mentions of attribution in the negotiation context were likely to be politically motivated, associated with attempts to push for compensation for climate change impacts. ${ }^{4}$ They also suggested that the political motivations might influence how attribution science would be represented, i.e. negotiators might "choose what they know" (Parker et al. 2017a). ${ }^{5}$ When developed countries mention attribution in UNFCCC negotiations they might highlight the uncertainty and imply inability to attribute losses and

\footnotetext{
${ }^{3}$ Recurring questions about whether L\&D is related to climate change, and specifically about attribution, were witnessed in our own participant observation of UNFCCC discussions (see Boyd et al. 2017), notably including one quote from a member of the Executive Committee to the WIM "it's a question of attribution which we always get back to". Interviewees (see Box 5.2) also commented on the recurring nature of the topic in UNFCCC discussions, for example "there's a lot of unproductive exchanges that say "how can we be sure this is related to anthropogenic changes," explaining "it's not an explicit agenda item, but it always pops up."

${ }^{4}$ For example, one interviewee said "When you talk about attribution, there's an important sense of who's paying for it and who's to blame... people look at attribution as a way to get compensation." ${ }^{5}$ Another interviewee said, referring to attribution science: "I think there will be different ways in which people interpret this and use this to get what they want, and to avoid having to do/pay for things."
} 
damages to anthropogenic forcing. ${ }^{6}$ Conversely, vulnerable countries might want to highlight the strength of attribution evidence to try to prompt action from emitters ${ }^{7}$ (see also chapter by Calliari et al. 2018).

Therefore, whilst on an institutional level it seems important to distinguish losses and damages which are attributable to climate change, and losses and damages which might not be relevant to the UNFCCC, doing so is not only scientifically challenging, but also politically contentious. Perhaps in order to make progress in the presence of this controversy, and to achieve agreement across different Parties, deliberately ambiguous language has been used in the official L\&D text under the UNFCCC, including in the Warsaw International Mechanism (WIM) (UNFCCC 2013) and Article 8 of the Paris Agreement (UNFCCC 2015). ${ }^{8}$ The WIM refers to L\&D from climate change impacts, but it is unclear how those losses and damages might be distinguished from L\&D from natural disasters (James et al. 2014a).

\subsubsection{Perspectives from Practitioners: Is It More Pragmatic to Avoid Isolating Anthropogenic Climate Change Impacts from Other Losses and Damages?}

The ambiguity in international policy leaves room for multiple perspectives on the relevance of anthropogenic climate change to $L \& D$, and the potential role for attribution science. Boyd et al. (2017) asked stakeholders whether they thought actions to address losses and damages should refer only to the impacts of anthropogenic climate change, or to any adverse effects from climate variability and change (see Fig. 5.1). This revealed a divide in opinion. In 9 of the 36 interviews, stakeholders were clear that, since the WIM was part of the UNFCCC, it should focus on anthropogenic climate change. Nine others, predominantly practitioners, argued that it would be more pragmatic to address all weather and climate-related losses and damages together (in keeping with several working definitions of L\&D, Warner and van der Geest 2013; UNEP 2016). ${ }^{9}$

Many of the remaining interviewees also expressed caution about limiting L\&D actions too strictly to those impacts that could be attributed to anthropogenic climate change. This was partly due to awareness of the political connotations of attribution

\footnotetext{
${ }^{6}$ For example, Vanhala and Hastbaek (2016) refer to the response of New Zealand to an AOSIS proposal, in which they rejected the proposal on the basis that it is not possible to attribute any specific extreme event to climate change.

${ }^{7}$ One interviewee discussed the challenge of attribution science for vulnerable countries: "the risk is that L\&D may well go unattributed to climate change and once the opportunity to compensate is lost, in the scheme of things it's lost...It's difficult, obviously you want to attribute everything."

${ }^{8}$ According to Vanhala and Hastbaek (2016), the ambiguous nature of the WIM was central to its establishment; or as one interviewee in Boyd et al.'s (2017) study stated "they've made it fuzzy to get people to sign on".

${ }^{9}$ In the remaining 18 interviews, a conclusive opinion about this question was not expressed.
} 


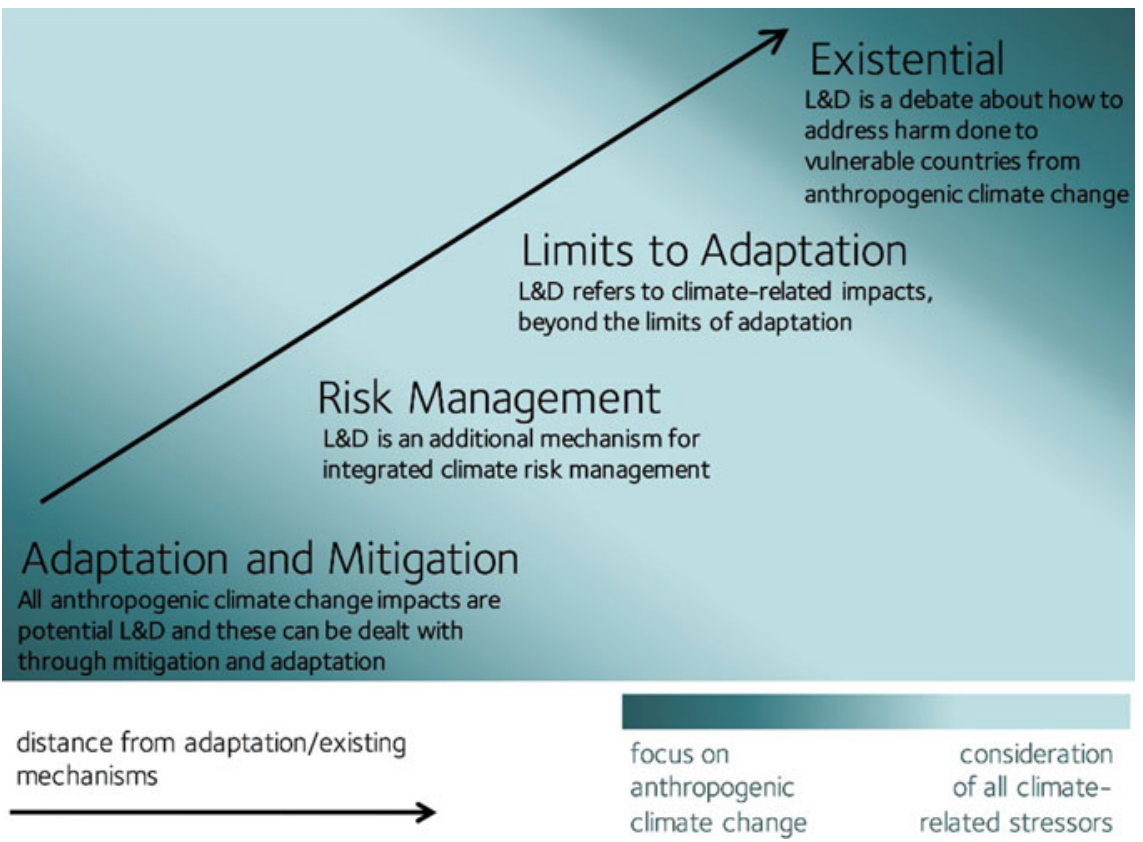

Fig. 5.1 A schematic diagram illustrating a spectrum of views on L\&D identified by Boyd et al. (2017). Each of the four perspectives are arranged along an axis in terms of how far suggested approaches to address losses and damages are distinct from, or go beyond, existing adaptation mechanisms. The shading illustrates how the perspectives differ in terms of the relevance of anthropogenic climate change: for two of the perspectives identified, $L \& D$ refers to anthropogenic climate change impacts only, for the other two perspectives, there is an emphasis on addressing all climaterelated risk. Adapted from Boyd et al. $(2016,2017)$

in the negotiations, ${ }^{10}$ and the suggestion that more progress might be possible if the mandate of L\&D mechanisms remained vague and inclusive. ${ }^{11}$ It was also partly due to frustration at the inefficiencies of multiple institutions in disaster risk, humanitarian aid, development, adaptation, and now potentially L\&D, working on separate but related issues without effective coordination ${ }^{12}$; and an appeal for more integrated risk

\footnotetext{
${ }^{10}$ This was expressed several times when this question was linked to issues of compensation and attribution by the interviewee, e.g. "to get political consensus around attribution, and therefore compensation, is just never going to happen."

${ }^{11}$ For example: "If you push too hard the discussion on defining, other than the quagmire semantics and politics it takes you into, it actually works against the idea that you have to address the problem comprehensively."

${ }^{12}$ For example: "There are too many forms of funding coming out of development, the problem with that is that you need a broad resilience approach to short term risk and long term stresses which can create conflict related to climate change."
} 
management. ${ }^{13}$ The suggestion that L\&D should refer to all climate-related events was also related to an expression of caution about relying too heavily on complex scientific assessments. ${ }^{14}$ Interviewees were concerned that uncertainties in the science could delay progress, ${ }^{15}$ or inhibit efforts in regions with limited data availability and limited ability to provide evidence of the influence of climate change. ${ }^{16}$ They suggested that the more important ethical imperative should be to help people who are suffering. ${ }^{17}$ This is also in keeping with comments expressed in the literature (e.g. Hulme et al. 2011). Several stakeholders suggested that focusing on attributing hazards would be counterproductive in diverting attention away from helping those in need. ${ }^{18}$

\subsubsection{A Challenge for Science-Policy Dialogue}

In policy (Sects. 5.2.1, 5.2.2) and practice (Sect. 5.2.3), questions about attribution may therefore emerge from questions about which institutions and countries should take responsibility for dealing with L\&D; about who should pay for L\&D. Many see that assigning responsibility is politically challenging, and addressing climate change impacts in isolation is impractical. Attribution, by association, is sometimes seen as unhelpful or irrelevant. ${ }^{19}$

For scientists, questions about attribution have different motivations, objectives, and implications. Analysis of causality is an important way to further understanding of the Earth System. There are many important reasons to ask attribution questions besides establishing responsibility. And, it is worth highlighting that the results of scientific attribution studies are not sufficient to indicate responsibility. Attribution studies can estimate the extent to which certain drivers (such as GHGs) contributed to certain outcomes (such as flooding), but this "contribution" is very different from

\footnotetext{
${ }^{13}$ For example: "disaster risk management thinking and also climate change thinking has to be integrated with this big development perspective."

${ }^{14}$ For example: "that places too great a weight upon scientific evidence in ethical and political negotiations, which cannot be borne by climatic science."

${ }^{15}$ For example: "We cannot wait for them [climatologists] to determine to what extent this is about climate change or not" (Parker et al. 2017a).

${ }^{16}$ For example: "Science can establish maybe for some impacts earlier than others, there's some differences", and "there's a big issue with that in that the data for developing countries, we have less certainty on what is climate enhanced disaster in the south, simply because we don't have the data sets. We don't have the information to say with certainty that that was caused by climate change."

${ }^{17}$ For example: "the more urgent issue is... actually... responding to or adapting to extreme weather events, whether it's caused by people or not".

${ }^{18}$ In the words of one interviewee: "trying to disentangle the climate change portion of that risk might be useful from a political point but it's actually counterproductive in terms of having an impact on reducing risk". Similar points were expressed by stakeholders interviewed specifically about attribution science (Parker et al 2017a).

${ }^{19}$ For example: "I know there's this question around attribution, if you think it is key, then the science is very important. In my mind it isn't and I don't think that is the way forward."
} 
"responsibility", which is a moral or ethical issue (Gardiner 2004; Muller et al. 2009; Skeie et al. 2017). Even where a scientific study might demonstrate that a country's, or company's, emissions contributed to a particular loss, that would not necessarily equate to responsibility to act or compensate, for example, if the emitter were unaware of the influence of their emissions. Ethical questions about responsibility extend far beyond the domain of climate science (ethical issues and perspectives are treated in the chapter by Wallimann-Helmer et al. 2018 of this book).

Yet many of the stakeholders interviewed appear to see a direct association between attribution and blame, liability, or compensation. ${ }^{20}$ Several also suggested that the motivation for attribution research is blame or compensation. ${ }^{21}$ This might explain why mentioning attribution science can receive a hostile, or wary, reception in many L\&D discussions. ${ }^{22}$ As one interviewee said: "the minute you talk about anthropogenic climate change, the purpose in talking about that is to figure out who is to blame and who to pay for the effects of it."

The assumption of political motives behind scientific inquiry or discussion poses a dilemma for science-policy dialogue: it is difficult to talk about attribution and climate change signals in connection with L\&D, but it seems important that policymakers are aware of what the science can offer, and what it cannot. And, if policy is to address losses and damages from climate change, it is important to understand changing risks. A central aim of attribution research, to investigate how rising GHGs are influencing climate and the occurrence of extreme weather events, would appear to be quite fundamental in order to prepare for climate change and address losses and damages.

Initial evidence suggests that the current understanding of attribution science amongst stakeholders involved in the L\&D discussions is quite limited (Parker et al. 2017a). There are several opinions about the science which were found amongst the interviewees which might be problematic. First, several implied that scientific evidence would later become stronger which would provide more evidence for policy, particularly for compensation. ${ }^{23}$ Whilst the science is advancing rapidly, some

\footnotetext{
${ }^{20}$ In many of the interviews, attribution was mentioned in the same sentence or fragment as blame, compensation, and liability, for example: "attribution and culpability of climate damage," "attribution of blame and taking compensation," "attribution, and therefore compensation," "the compensation or liability issues, as well as attribution," "how do you attribute and get compensation." This was often with the implication that the main purpose of attribution is to establish responsibility, or that the only reason why attribution would be needed is to establish responsibility e.g. "Is this about making an argument that there is an ethical responsibility on polluters to compensate for damage caused by pollution. In which case, attribution of weather events to particular cases in the atmosphere becomes important".

${ }^{21}$ For example: "There will at some point be a growing need for a politically motivated answer that looks at attribution, but the reason for that is not practical it is political", and: "climate attributions are trying to understand what's climate change doing to extremes and slow onset events and suggesting that this can create a call for compensation"

${ }^{22}$ Based on research team's experience of attending $>20$ meetings with a focus on L\&D (Boyd et al. 2017).

${ }^{23}$ For example: "the science ... that's kind of the one thing that's lagging" and "that issue of attribution around which political consensus will not occur in the next 5 years or 10." One interviewee
} 
uncertainty will always remain, and it is important to help these stakeholders understand what the science might be able to offer, and where it might be insufficient. On the other hand, many other stakeholders highlighted the challenges and difficulties of attribution, ${ }^{24}$ some even saying that it is impossible,${ }^{25}$ which perhaps misses an opportunity, as there may be useful research available which they are unaware of. In the next section, we review sources of attribution evidence to examine the extent to which they might provide useful information about the changing risk of losses and damages.

\subsection{The Science of Attribution: What Kind of Evidence Is Available About the Influence of Anthropogenic Climate Change on L\&D?}

Climate change attribution research initially focused on investigating drivers of observed global warming (e.g. Tett et al. 1999; Stott et al. 2000). However global mean surface temperature does not have direct influence on people or infrastructure. Attribution of losses and damages is a much more challenging and more interdisciplinary scientific problem.

Attributing losses and damages involves investigating how anthropogenic GHGs influence many other climatic variables besides global temperature, as well as their influence on the oceans, cryosphere and biosphere, on a range of timescales. UNFCCC documents (e.g. UNFCCC 2013, 2015) consistently state that losses and damages refers to impacts from both extreme events (including heatwaves, flooding, tropical cyclones, and drought), and "slow onset" events or climatic processes (including glacier retreat, sea level rise, ocean acidification and desertification). ${ }^{26}$ Understanding this wide range of environmental processes requires input from many different scientific disciplines (from physical climate science, to hydrology, to ecology, to economics), and collaboration between them. It is worth highlighting that the

\footnotetext{
described attribution science as the key to unlocking liability, implying that it would later emerge: "we don't have to enter the rooms on liability and compensation, those doors are locked behind a door called attribution. The key to that door lies with the scientific community, it is still being forged."

${ }^{24}$ For example: "Attribution is just really difficult," "as we know attribution is very difficult," and "the whole attribution thing is tricky."

${ }^{25}$ On being asked whether L\&D should refer to L\&D which can be attributed to anthropogenic climate change, or all climate-related $L \& D$, one interviewee said "there's no science that can distinguish between the two," and another said "I think in many cases, it's just simply impossible to differentiate between the two. And I cannot think about one methodology that would allow a small island state to argue whether a storm surge is part of a natural variability or climate change."

${ }^{26}$ In decision 1/CP.16 (UNFCCC 2011), it was noted that approaches to address losses and damages should consider climatic impacts "including sea level rise, increasing temperatures, ocean acidification, glacial retreat and related impacts, salinization, land and forest degradation, loss of biodiversity and desertification"
} 
distinction in policy, between extreme events and slow onset events, is not consistent with the way the events are studied by scientists; and losses and damages in many cases result from the interplay between incremental change (including "slow onset processes") and rare (extreme) events. For instance, sea level rise is often experienced through an increase in the height of storm surges. Gradually increasing temperatures may have their largest impact during a drought.

Attribution to anthropogenic climate change requires a comparison between the influence of human GHGs and the influence of other potential drivers. The first climate change attribution studies compared the "forcing" on global temperature from anthropogenic GHGs and aerosols, with natural drivers including solar variations and volcanic aerosols (Tett et al. 1999; Stott et al. 2000). Attribution of global temperature also, importantly, considers the role of natural modes of variability, such as the El Nino Southern Oscillation or Atlantic Multi-Decadal Oscillation (e.g. Fyfe et al. 2010; Foster and Rahmstorf 2011; Folland et al. 2013), which can modify the global temperature from year to year or even decade to decade (Parker et al. 2007). At a regional or local scale, the role of natural variability on weather and climate is even more pronounced, and it is therefore a very important factor to consider in attribution of losses and damages. In addition, the climatic and environmental hazards which lead to losses and damages have many other drivers besides anthropogenic emissions and natural variability, for example changes in land use (such as deforestation, urbanisation, agricultural development) which have important influences, for example via the hydrological cycle, meaning more confounding variables need to be taken into account in an attribution analysis.

To understand losses and damages, it is essential to not only study drivers of environmental hazards, but also to investigate other components of risk: influences on exposure and vulnerability (Huggel et al. 2013; chapters by Bouwer 2018; Schinko et al. 2018; Lopez et al. 2018; Botzen et al. 2018). The extent of losses and damages during a flood, for example, will be determined by the scale of the meteorological and hydrological hazard, but also the exposure of populations (are there people living in the floodplain?), and their vulnerability (are houses flood-resilient? are there early warning systems and procedures for emergency response? do people have insurance?). Furthermore, losses and damages might include monetary losses, loss of life, damage to infrastructure, detrimental effects on ecosystems, and a diverse array of non-monetary or non-economic losses and damages (NELs/NELD), such as loss of identity, or psychological distress (Serdeczny et al. 2016; Clayton et al. 2017; chapter by Serdeczny 2018). Attribution of such a range of quantifiable and non-quantifiable variables poses further uncertainties and challenges.

Attributing losses and damages may start to sound like an impossible challenge. As we will explore, it is not currently possible, and it may never be possible, to generate a complete inventory of losses and damages from anthropogenic emissions. Yet that should not prevent scientists from seeking to develop a fuller understanding of the drivers of losses and damages, and it does not mean that the science that is already available is not useful for policy-makers, who are accustomed to dealing with incomplete information and uncertainties. There are several important fields of enquiry which can already contribute evidence to help us understand how anthro- 
pogenic climate change is influencing losses and damages, and steps are already being made to integrate these disciplines. For example, recent work has estimated the monetary losses attributable to anthropogenic emissions from damage to housing following the 2013/2014 winter flooding in the UK (Schaller et al. 2016), and the number of heat-related deaths attributable to anthropogenic emissions during the 2003 European heatwave (Mitchell et al. 2016).

Here we review fields of study that might contribute to more such analyses in the future, for each giving a brief overview of how the science works, examples of the kind of attribution findings it can deliver, an evaluation of the strength of evidence which is currently available, and future directions in the field. Given the scale of the challenge, we cannot not hope to be comprehensive, but rather to give an introduction alongside references which could provide more detailed insights. Figure 5.2 summarises some of the causal connections between anthropogenic activity and losses and damages, and illustrates contributions from the different scientific fields described in Sects. 5.3.1-5.3.4. Several authors have described a "causal chain" between anthropogenic emissions, climate and weather, and local impacts (Stone and Allen 2005; Hansen et al. 2016). Here we show there are many interacting causal chains, which might be conceived of as a web or network of natural and anthropogenic interactions.

\subsubsection{Attribution of Climate Change and Extreme Weather Events to Anthropogenic Forcing}

The science of attributing observed climate and weather to external drivers, including attribution of climate change trends, and attribution of extreme weather events, is the type of research which physical climate scientists are usually referring to when they use the term "attribution," and this is also how "attribution" is used in the IPCC Working Group I (WGI) reports (Bindoff et al. 2013). Here, attribution is defined as "the process of evaluating the relative contributions of multiple causal factors to a change or event with an assignment of statistical confidence" (Hegerl et al. 2010: 2; Bindoff et al. 2013: 872). The aim is to investigate the influence of human-induced changes in GHGs and other short-lived climate forcers (SLCFs) on climate or extreme weather events, relative to the influence of other drivers, including modes of natural climate variability, solar variability, and volcanic eruptions. The studies usually focus on climate and weather, and therefore do not necessarily provide information about impacts or losses and damages, therefore the results are most relevant for the links shown in the top left of Fig. 5.2. What follows is a brief overview of the relevance of attribution research to L\&D. For more detailed information, several reviews are available (Hegerl and Zwiers 2011; Bindoff et al. 2013; Stott et al. 2016; National Academies of Sciences, Engineering, and Medicine 2016).

Until very recently climate change attribution studies analysed trends, most notably the increase in global mean surface temperature. In these attribution studies, 


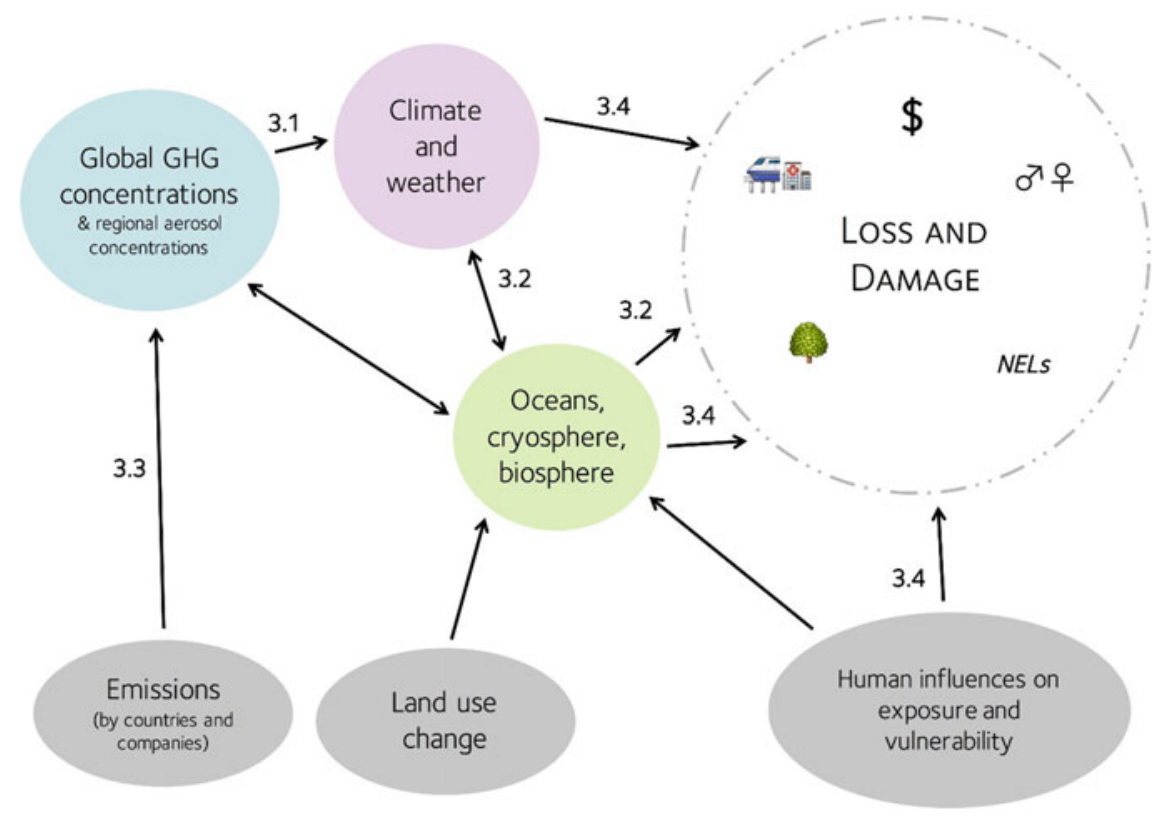

Fig. 5.2 A conceptual causal network illustrating multiple potential "causal chains" between anthropogenic changes in GHGs and aerosols, climate and weather, and L\&D. The figure is designed to be illustrative rather than comprehensive, showing the influence of human factors (shown in grey at the bottom of the figure) on L\&D, including monetary losses, fatalities, damage to infrastructure and ecosystems, and non-economic losses (NELs). The arrows are labelled with the section of the chapter which deals with scientific research relevant to that link in the network: importantly not all of the links are labelled, highlighting again that this chapter is not comprehensive, and there may be other fields of research which could be integrated into L\&D research and practice to better understand L\&D

observed trends are compared to model simulations with and without certain drivers (including GHGs, anthropogenic aerosols, solar variability, and volcanic aerosols) to test the relative importance of each forcing factor (see Fig. 5.3). These studies have demonstrated that anthropogenic activity has influenced global warming, and also regional warming on six continents, as well as global changes in related variables, such as atmospheric water vapour. The global increase in sea level rise has also been attributed to anthropogenic GHGs (Bindoff et al. 2013). Trend attribution can therefore provide relevant information about the influence of climate change on some "slow onset" events including sea level rise, and increasing temperatures. It is also possible to conduct trend attribution studies on long term trends in extreme weather events, for example the global increase in heavy precipitation events has been attributed to anthropogenic emissions (Zhang et al. 2013).

In the last 10 years, a new field of climate change attribution research has rapidly emerged, which focuses on single extreme weather events (Stott et al. 2016). It is now possible to make statements about how anthropogenic emissions have influenced specific heatwaves, heavy rainfall events, wind storms, and droughts. Since 


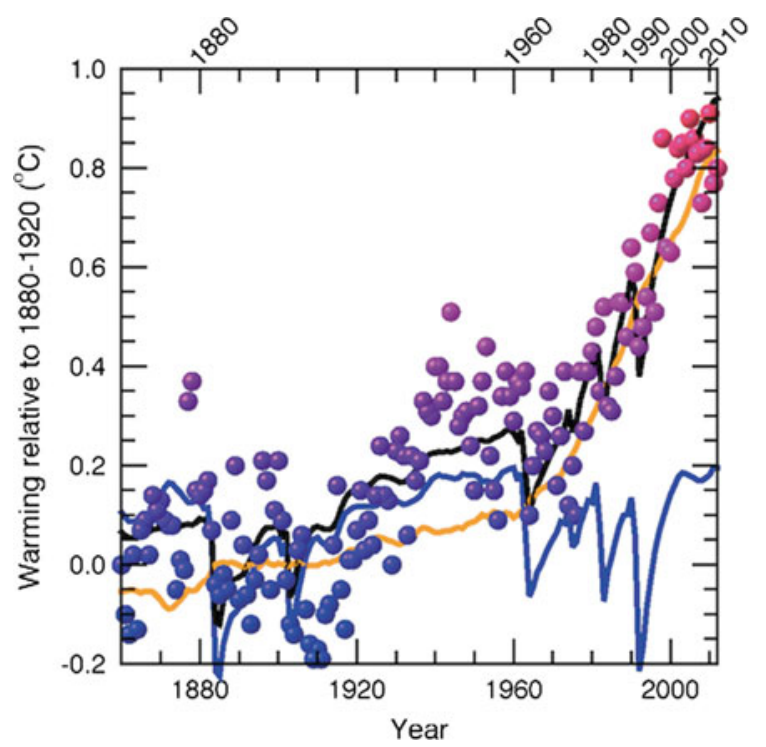

Fig. 5.3 Example of a simplified detection and attribution study for global temperature. Points show observed global temperature anomalies relative to 1880-1920 (shaded blue to pink to represent cooler to warmer temperatures). These are compared to model simulated temperatures with natural forcings only (blue), anthropogenic forcing only (orange), and a combination of natural and anthropogenic forcings (black). As shown, the observations can only be reproduced with both natural and anthropogenic forcing. Source Bindoff et al. (2013) IPCC AR5 WGI, Box 10.1 Fig. 1, p. 876

extreme weather events are rare, and their occurrence is strongly influenced by natural variability, it is not possible to say that a specific event would not have occurred without anthropogenic interference. However, it is possible to investigate whether and how anthropogenic emissions influenced the probability and magnitude. There are several different methods for examining the influence of anthropogenic climate change on extreme weather events, including observational and model-based studies (Stott et al. 2016). All methods use either large ensembles of climate models or statistical models to estimate the likelihood of an event occurring in the current climate as well as with the anthropogenic climate drivers removed. The resulting frequency distributions can be used to estimate the change in the probability due to anthropogenic interference (as in Fig. 5.4).

Extreme event attribution studies are increasingly being applied to understand contemporary extreme events, and for the past 6 years the Bulletin of the American Meteorological Society has published a summary of attribution studies referring to the previous year (Peterson et al. 2012, 2013; Herring et al. 2014, 2015, 2016, 2018). The science is advancing rapidly, evidenced in the large growth in the number of studies published, and the ability to make attribution statements more quickly: scientists are investigating the possibility of operational event attribution which could deliver statements in the weeks and months following an event 


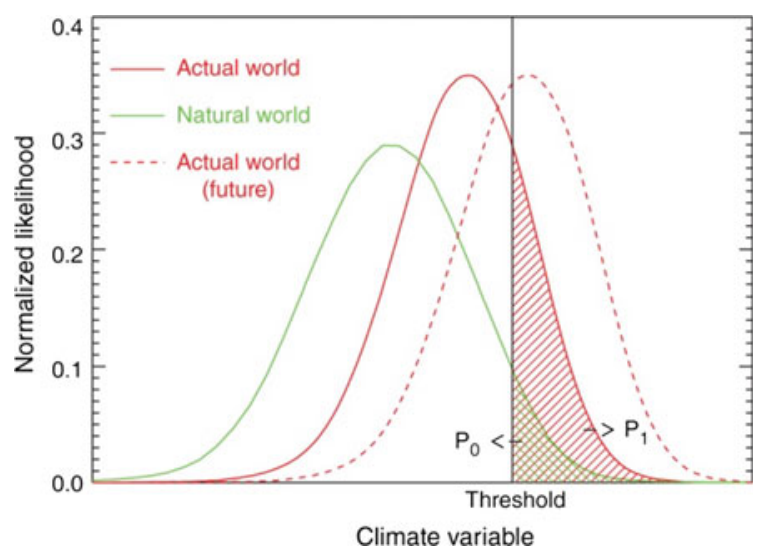

Fig. 5.4 A schematic illustration of the probability distribution of a climate variable (such as temperature or precipitation) with (solid red line) and without (green line) human influence on climate. Extreme event attribution studies use statistics or climate models to estimate these distributions and then calculate the change in probability associated with anthropogenic forcing (i.e. the difference between the green hatched area $-\mathrm{P}_{0}-$ and the red hatched area- $\left.\mathrm{P}_{1}\right)$. The red dashed line illustrates how the probability distribution of the variable might change in future. Source Stott et al. (2016)

(see www.climatecentral.org). For example, the flooding in Louisiana in August 2016 was attributed to have been made twice as likely due to anthropogenic climate change, two weeks after the event occurred (van der Wiel et al. 2017). A large signal from anthropogenic climate change on the early 2017 drought in Kenya could be excluded while the event was still unfolding (Uhe et al. 2017).

It is currently not possible to conduct scientifically viable attribution studies for all types of extreme weather events leading to losses and damages (see Fig. 5.5), and some specific cases can be particularly difficult to model due to rare and complex weather patterns, as was found for flooding in Pakistan in 2010 (e.g. Christidis et al. 2013). There are also important variations in the availability and quality of attribution evidence between regions. Currently, many more studies have been conducted for developed than developing countries (Otto et al. 2015a). There are efforts to change this (e.g. wwa.climatecentral.org), but limited availability of data in developing countries is a barrier (Huggel et al. 2015a). This is highly relevant for L\&D, because it means it is challenging to make attribution statements about losses and damages from some disasters. It is also important to highlight that in some cases anthropogenic climate change is found to decrease the probability of extreme events, such as spring flooding from snowmelt in the UK (Kay et al. 2011) or not to alter the likelihood of the event occurring, as for the 2014-15 droughts in the Sao Paolo area (Otto et al. 2015b).

Uncertainties associated with event attribution studies can make the results challenging to communicate and apply in policy (Otto et al. 2015a), as with projections of climate change (Weaver et al. 2013). The results of attribution studies also depend on 


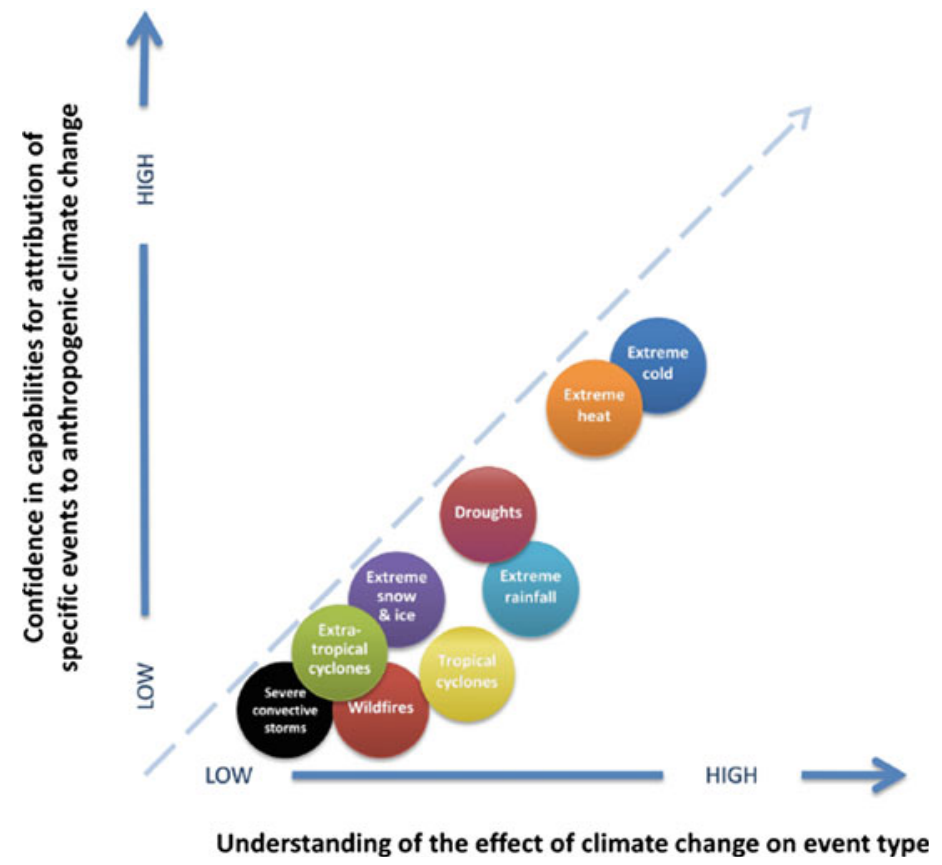

Fig. 5.5 Schematic illustration of the assessment by the National Academy of Sciences of the state of attribution science for different types of extreme weather events, both in terms of the general understanding of the impact of climate change on this kind of events, and in terms of the attribution of specific extreme events to anthropogenic forcing. Source National Academies of Sciences, Engineering and Medicine (2016)

how events are defined, how attribution questions are asked, and the methodologies used (Dole et al. 2011; Rahmstorf and Coumou 2011; Otto et al. 2012), which has led to some disagreements between scientists about the strength of evidence which they provide (Trenberth et al. 2015; Otto et al. 2016). This does not preclude the use of evidence about changing risks from attribution studies, but highlights a need for research to explore how the science might contribute to decision analyses (see chapter by Lopez et al. 2018; chapter by Botzen et al. 2018), potentially building on existing efforts to combine and translate sources of uncertainty into a common confidence language (Stone and Hansen 2016).

As GHG concentrations increase, and the Earth System adjusts to this perturbation to the energy balance, the signal from climate change will be strengthened, and therefore it is likely that the Earth will experience more regional changes, and more extreme events which show a detectable influence from anthropogenic emissions (e.g. Lee et al. 2016; Frame et al. 2017). The rapid developments in the science also suggest that there will be a continued growth in available literature, and now there are also increasing efforts to extend extreme event attribution studies beyond climatic variables to also consider ecological and hydrological impacts (e.g. Marthews et al. 
2015; see Sect. 5.3.2), loss of life (Mitchell et al. 2016), and monetary losses (Schaller et al. 2016), as well as linking with research into the sources of anthropogenic forcing (see Sect. 5.3.3). However, it is worth highlighting that some uncertainties in the science will not be eliminated, and the research is unlikely to provide an even evidence base for all countries and events: some events will always be easier to study due to differences between events in the strength of the climate signal, availability of data, and ability of models to simulate them.

\subsubsection{Attribution of Climate Change Impacts}

There is a growing body of evidence about how recent changes in climate have influenced natural and human systems. As part of the IPCC AR5 Working Group II (WGII) report this evidence is drawn together to assess the detection and attribution of climate change impacts on the cryosphere, water resources, coastal systems, terrestrial and oceanic ecosystems, and on human systems, including analysis of food systems and the livelihoods of indigenous people (Cramer et al. 2014). In this context, attribution "addresses the question of the magnitude of the contribution of climate change to change in a system" (Cramer et al. 2014, 985), and that contribution is evaluated as being "major" or "minor". This is a slightly different approach to the attribution of climate changes and weather events in WGI (Sect. 5.3.1; see Fig. 5.6), and in particular, does not necessarily imply that the change in question
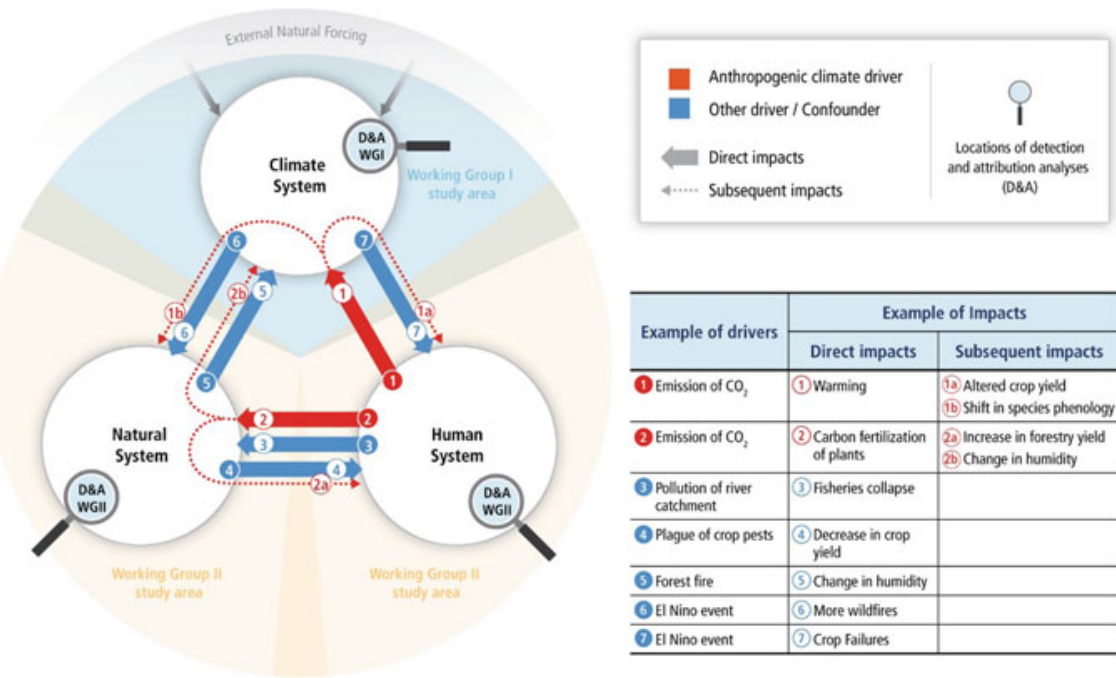

\begin{tabular}{|c|c|c|}
\hline \multirow{2}{*}{ Example of drivers } & \multicolumn{2}{|c|}{ Example of Impacts } \\
\hline & Direct impacts & Subsequent impacts \\
\hline (1) Emission of $\mathrm{CO}_{2}$ & (1) Warming & $\begin{array}{l}\text { (13) Altered crop yield } \\
\text { (ib) Shift in species phenolog? }\end{array}$ \\
\hline (2) Emission of $\mathrm{CO}_{2}$ & $\begin{array}{l}\text { (2) Carbon fertilization } \\
\text { of plants }\end{array}$ & $\begin{array}{l}\text { (20) Increase in forestry yield } \\
\text { (2) Change in humidity }\end{array}$ \\
\hline $\begin{array}{l}\text { (3) Pollution of river } \\
\text { catchment }\end{array}$ & (3) Fisheries collapse & \\
\hline (1) Plague of crop pests & $\begin{array}{l}\text { (4) Decrease in crop } \\
\text { yeld }\end{array}$ & \\
\hline 5 Forest fire & (5) Change in humidity & \\
\hline 6) El Nino event & (6) More wildfires & \\
\hline (2) El Nino event & (7) Crop failures & \\
\hline
\end{tabular}

Fig. 5.6 Schematic diagram from the IPCC WGII Chap. 18 on detection and attribution of observed impacts, which illustrates how WGII work on impacts attribution (here Sect. 5.3.2) relates to WGI work on attribution of climate and weather (here Sect. 5.3.1) and wider research into changes in climate, natural, and human systems. Source Cramer et al. (2014) IPCC AR5 WGII, Fig. 18-1, 985 
can be traced back to anthropogenic emissions. Given the challenges of attribution to anthropogenic emissions for certain variables, notably precipitation changes, this flexible approach allows for evidence to be gathered even where the signal-to-noise ratio from anthropogenic activity is so far small.

The basic premise of impacts attribution research is consistent with the atmospheric research (Sect. 5.3.1). Once a change in a certain variable has been detected, potential drivers of that change are compared: the influence of regional or local climate change is compared with other confounding variables such as pollution and land use change, and sometimes technological innovation, or social and demographic changes. The precise methodologies vary between disciplines (Stone et al. 2013), but for a causal relationship to be established it is essential to understand the processes by which climate change contributed to the observed impact, which is often explored using ecological, hydrological, agricultural, or epidemiological models.

Over the past couple of decades, evidence about the observed impacts of climate change has grown substantially (Hansen 2015). In the IPCC report of 2001, strong evidence was restricted to the cryosphere and terrestrial ecosystems in northern latitudes or mountainous regions (Gitay et al. 2001; Arnell et al. 2001). In the AR5, impacts of recent climate change were observed on all continents and across all oceans. There is high confidence that worldwide glacial retreat, permafrost warming and thawing, and mass bleaching of coral reefs can be mainly attributed to climate change. There is evidence that the livelihoods of indigenous people in the Arctic have been altered by climate change, and emerging evidence for indigenous people in other regions (Cramer et al. 2014).

As might be expected, understanding causal relationships is very challenging for human systems, and there is often a strong role for social and economic factors, making it difficult to isolate the role of climate change (Cramer et al. 2014). Hansen and Cramer (2015) also highlight that the availability of evidence varies markedly between regions. Often there is less evidence available about impacts in regions considered to be most vulnerable to climate change: suggesting that the lack of evidence does not indicate that climate change impacts have not occurred, but rather than there are fewer studies available. For example, between 2000 and 2010, 10,544 scientific studies were published about climate change impacts in Europe, and just 1987 about South America (ibid).

Increasingly, there are efforts to analyse whether impacts attributed to climate change can also be attributed to anthropogenic emissions, as well as to extend extreme event attribution studies of weather to also investigate impacts (i.e. linking Sects. 5.3.1 and 5.3.2). Attribution to anthropogenic emissions has been demonstrated for global scale studies of shrinking glaciers (Marzeion et al. 2014), ecological studies at a global aggregate level of a meta-analysis (Rosenzweig et al. 2008), changing water runoff, for example in the western United States (Barnett et al. 2008), and changes in ecosystem productivity (Sippel et al. 2018). Hansen and Stone (2016) analysed the role of anthropogenic emissions across all of the impacts assessed in the IPCC WGII report (Cramer et al. 2014), and found that approximately $65 \%$ of the impacts related to changes in atmospheric or ocean temperature could be confidently attributed to anthropogenic forcing (Fig. 5.7). The strongest evidence exists for shrinking glaciers, 


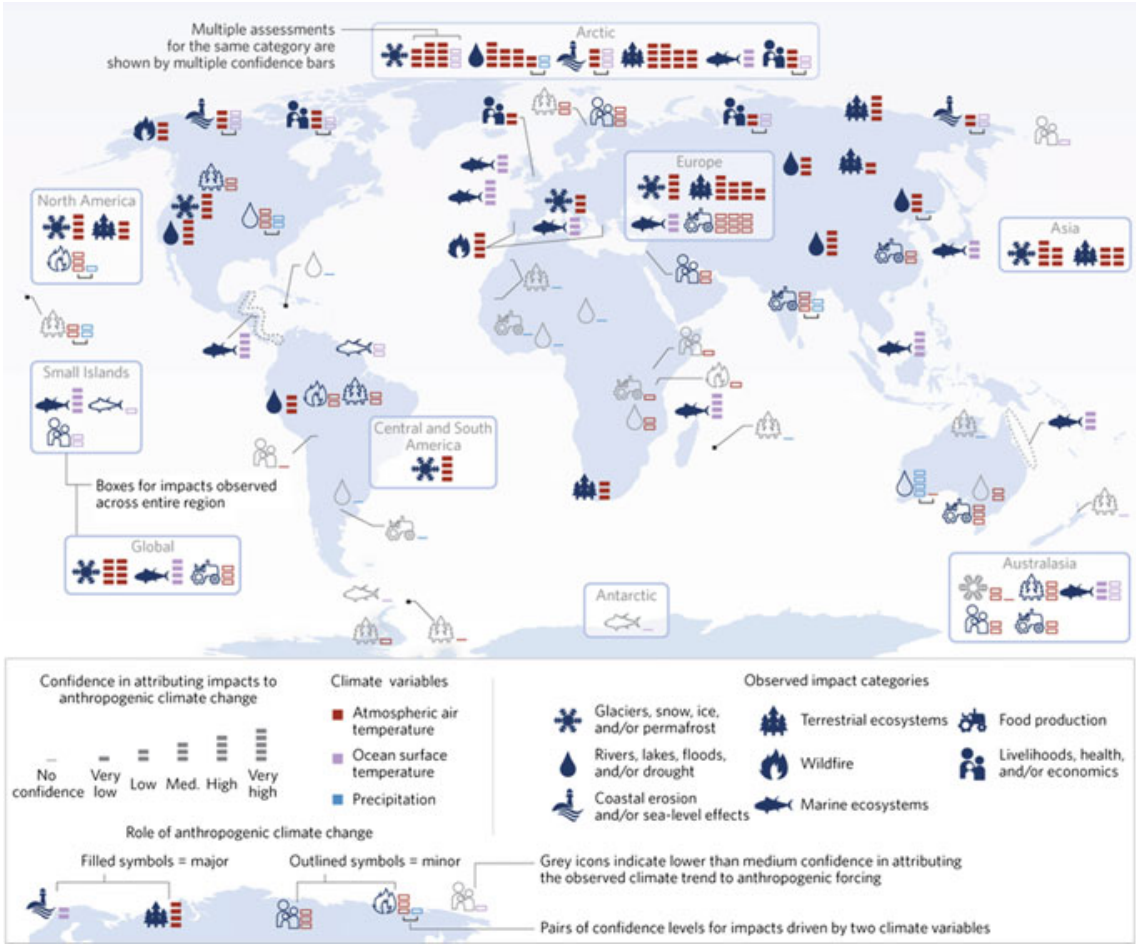

Fig. 5.7 An analysis by Hansen and Stone, revisiting impacts in the IPCC WGII report to assess whether they can be linked to anthropogenic forcing. Note Blue symbols show impacts which have been attributed to anthropogenic forcing with at least medium confidence, and confidence bars indicate the confidence level, with the colour of the confidence bars indicating whether the observed impact is related to changes in air temperature (red), ocean surface temperature (violet) or precipitation (blue). Impacts that are linked to regional climate trends, but with little evidence for anthropogenic forcing are shown in grey. Source Hansen and Stone (2016)

permafrost degradation, bleaching and decline of coral reefs, increasing forest fires, and the increase in shrub cover in Arctic regions. For impacts-related to precipitation, the evidence of anthropogenic forcing is still weak, and for many impacts, the evaluation of the relative contribution of anthropogenic climate change is still qualitative. It is currently difficult to make quantitative statements due to the limited availability of long-term, high quality data on the potential (non-climatic) drivers of change required to perform a comprehensive analysis.

However, despite the remaining gaps and challenges, there is already substantial evidence available about the attribution of climate change impacts (see Fig. 5.7), which can contribute to an understanding of how anthropogenic climate change is influencing losses and damages. The steps taken to integrate impacts research (Sect. 5.3.2) with climate research (Sect. 5.3.1), are promising, and several authors have proposed frameworks, and provided examples to illustrate, "end-to-end" attri- 
bution (Stone and Allen 2005; Stone et al. 2013; Huggel et al. 2015a; Hansen et al. 2016), which might be useful for further research. There is a question about whether this constitutes true "end-to-end" attribution in the case of L\&D. Do all climate change impacts constitute L\&D? It is notoriously unclear exactly how L\&D should be defined, but it is perhaps worth considering various other elements which might contribute to an "end-to-end" attribution of L\&D, including extending the "causal chains" from emissions to emitters (Sect. 5.3.3), and towards disaster losses (Sect. 5.3.4). It is also worth considering which of the impacts attributed (in e.g. Fig. 5.7) might already be considered L\&D. Recent event attribution studies have analysed monetary losses from flooding (Schaller et al. 2016); and loss of life from cold- and heat-related events (Christidis et al. 2010; Mitchell et al. 2016). Huggel et al. (2016a) also examine the Hansen and Stone (2016) data (Fig. 5.7) to consider which impacts constitute irreversible losses, finding evidence for the attribution of irreversible loss of glaciers, coral reefs, or livelihoods of Arctic communities.

\subsubsection{Attributing Anthropogenic Forcing to Regions, Countries, and Sectors}

IPCC (2013) stated "Human influence on the climate system is clear." This overarching statement can be decomposed on the response side of the cause-effect chain in terms of various types of impacts and their regional distribution (Sects. 5.3.1, 5.3.2). But it is also possible to do so on the driver side - along several dimensions. Firstly, there are different emissions and surface changes that perturb the radiative balance of the earth-atmosphere system and cause radiative forcing; greenhouse gases such as $\mathrm{CO}_{2}, \mathrm{CH}_{4}$ and $\mathrm{N}_{2} \mathrm{O}$, aerosols such as sulphate and black carbon, and albedo changes from land surface changes. Secondly, these factors also have a regional resolution; i.e., the emissions and changes in albedo from land use changes can be distributed to regions and nations, and economic sectors. Thirdly, these changes have occurred at different points in time; e.g. early deforestation and coal burning versus late emissions from more modern sectors (e.g. aviation) and technologies (e.g. halogenated gases). Several studies have quantified contributions to climate change by regions (den Elzen et al. 2005), nations (e.g. Matthews 2016; Skeie et al. 2017), sectors (e.g. Fuglestvedt et al. 2008) and even companies (Heede 2014).

To investigate the contributions to climate change, simple climate models are used to test the influence of specified quantities of emissions, or types of radiative forcing, on climatic changes, primarily global temperature. Contributions to climate change are often defined in counterfactual terms; i.e., how would the change in the chosen climate indicator (usually global mean surface temperature) be different if a particular subset of emissions were removed? A large number of simulations are used to test many different subsets of emissions. Due to non-linearities the individual contributions do not necessarily add up to $100 \%$ and there are various methods to adjust for this. Availability of emissions data is also a key issue. Various emission 


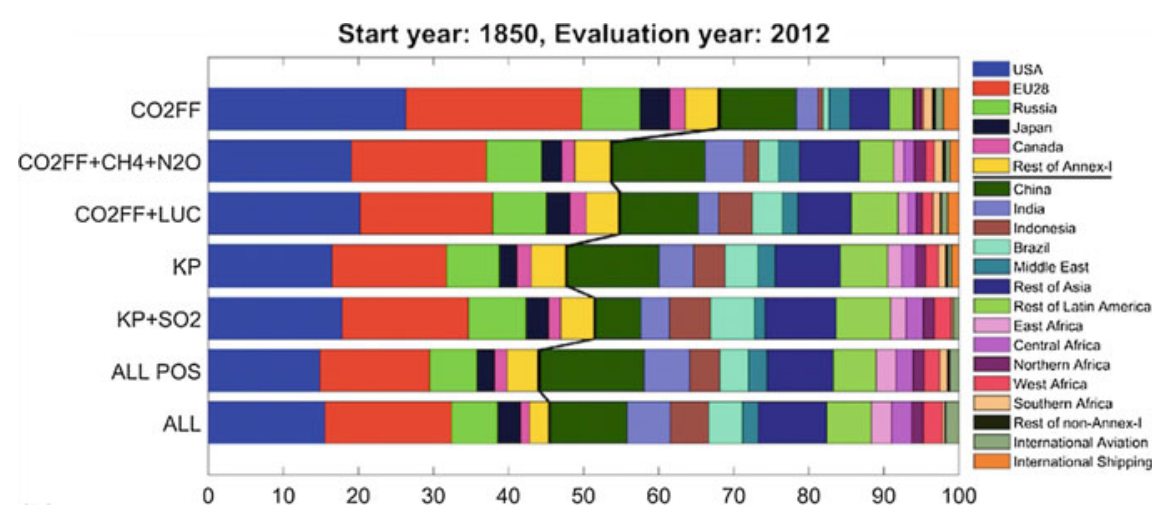

Fig. 5.8 Sensitivity of estimated contributions to global mean surface temperature increase to the choice of forcing components included in attribution analysis. $\mathrm{CO}_{2} \mathrm{FF}: \mathrm{CO}_{2}$ from fossil-fuel combustion and cement production. LUC: Land use change. KP: Kyoto Protocol gases $\left(\mathrm{CO}_{2}, \mathrm{CH}_{4}\right.$, $\mathrm{N}_{2} \mathrm{O}, \mathrm{HFC}, \mathrm{SF}_{6}, \mathrm{PFC}$ ). ALL POS: All warming components. Source Skeie et al. (2017)

databases and inventories are used and often assumptions and inter/extrapolations are needed (see Skeie et al. 2017).

The results of these studies depend strongly on various choices taken during the analysis. Among the choices that have to be made are start and end dates for emissions that are considered, when to measure the effect of the emissions, what indicator of climate change is chosen (temperature, precipitation, extremes, sea level rise, etc.), which drivers (GHGs, aerosols, land use changes) are included, how to frame the emissions by the selected entities (extraction/territorial/consumption based emissions), and whether the contributions should be normalised by population size. An alternative could also be to normalise the contributions by the Gross Domestic Product (GDP) of the countries. Figure 5.8 shows how the choice of emission components included can impact the resulting calculations of how much each region or country has contributed to change in global mean surface temperature up to 2012 (Skeie et al. 2017).

As discussed by Skeie et al. (2017), and Fuglestvedt and Kallbekken (2015) there is no simple and single answer to the contribution question. Thus, it is not straightforward to ask how much a particular country, company, or sector contributed to observed global warming. The answer varies depending on many choices in the methodology, and these choices are associated with many open value-related and ethical questions. Scientists might therefore best support policy-makers by presenting a spectrum of results showing how the calculated contributions vary according to various choices.

A natural research question to ask is whether it will be possible to go further and attribute other implications of climate change to nations' emissions. Otto et al. (2017) for the first time explore the link between emissions from countries to radiative forcing and temperature contributions, and changes in the probability of extreme weather 
events, demonstrating how this area of work might be integrated with attribution of climate and weather events (Sect. 5.3.1) and impacts (Sect. 5.3.2).

\subsubsection{Assessing and Analysing Losses and Damages from Disasters}

To understand L\&D from anthropogenic climate change, it is also important to consider disaster assessments and disaster research. Before the establishment of L\&D as an area within the UNFCCC, there was already a great deal of work seeking to quantify and analyse losses and damages from natural hazards. Not all of this work examines causality, and therefore might not be considered attribution research, but integrating knowledge, expertise, and analysis tools from disaster research with climate change and climate impacts attribution research (Sects. 5.3.1, 5.3.2, 5.3.3) could be a fruitful way to obtain a fuller understanding of L\&D, and in particular to compare the influence of anthropogenic climate change with drivers of exposure and vulnerability.

Loss and damage assessments are routinely conducted after major disasters, and the results are widely available in disaster databases including at global (EM-DAT: Guha-Sapir et al. 2009; DesInventar 2015), and national levels. Reinsurance companies also hold disaster databases,${ }^{27}$ but these are generally not publically available. Disaster databases represent an impressive resource, however the quality, consistency and completeness varies between regions and between events. The results also vary between datasets: there is no consensus about how to collect data following disasters (Huggel et al. 2015b), and different methodologies can have quite different results (Kron et al. 2012). Collecting data about losses and damages from slow onset events such as drought is very challenging, due to the timescales of data collection, and the many other drivers which might play a role over this longer time period. Developing countries are poorly represented (Gall et al. 2009), and in particular there is a lack of information at the subnational scale in vulnerable countries (Huggel et al. 2015b).

Disaster risk research uses these databases to examine trends in losses from disasters, including extreme weather events, and including analysis of causal relationships with climatic variability (Bouwer 2011; chapter by Bouwer 2018). It is generally accepted that the observed global increase in disaster losses is largely attributable to increases in exposure to hazard, with more wealth situated in locations that are at risk (Bouwer 2011; IPCC 2012). Research on the role of changes in vulnerability on observed losses and damages is still very scarce and needs to be investigated in more detail, although there is evidence that vulnerability to flood hazard is decreasing in some places (Mechler and Bouwer 2015; Jongman et al. 2015; Kreibich et al. 2017). Disaster databases often focus on a few key variables such as monetary losses and fatalities. The range of losses and damages considered under the UNFCCC extends far beyond these quantities (Serdeczny et al. 2016) and therefore it is also important

\footnotetext{
${ }^{27}$ E.g. www.munichre.com/natcatservice; www.swissre.com/sigma.
} 
to consider social science research to understand losses from disasters at a local level (e.g. Warner and van der Geest 2013).

Perhaps the greatest opportunity for integration with attribution research lies with "disaster forensics" and related fields which seek to examine past disasters, and draw lessons for future disaster risk management (e.g. Keating et al. 2016). Techniques include root-cause analysis (Blaikie et al. 2014), meta-analytical reviews (Mitchell 1999), longitudinal analysis of multiple disasters in a specific location (Erikson 1976; Oliver-Smith and Hoffman 1999; Kreibich et al. 2017), and retrospective scenarios (Jones et al. 2008).

\subsection{Policy Implications: How Might Attribution Science Be Applied to Support Actions to Address Losses and Damages?}

To date, it has been challenging to initiate detailed conversations in the policy arena about the potential relevance of attribution science to L\&D: in part due to the controversy surrounding $L \& D$, and the association which is often made between attribution and responsibility, blame, and liability (see Sect. 5.2). In this chapter we seek to highlight that attribution science itself does not aim to establish responsibility; and to outline some of the motivations, methods, and findings of different forms of attribution research, also considering how the integration of these fields could lead to a fuller understanding of the influence of anthropogenic climate change on losses and damages (Sect. 5.3). Now, having reviewed the available attribution evidence, we consider whether this science might have any useful applications to support L\&D mechanisms, policies, and practice.

Many attribution scientists have suggested that their research could be useful for adaptation and/or L\&D (e.g. Pall et al. 2011; Mitchell et al. 2016; Parker et al. 2017b). Parker et al. (2017a)'s literature review highlighted that climate scientists frequently refer to the potential applications of PEA. However, they found that in the L\&D literature itself, including, for example, publications from non-governmental organisations, there was little mention of attribution science. This suggests that there is a need for science-policy dialogue to explore potential applications (in agreement with e.g. Stott and Walton 2013); and to this end, there have already been a number of studies involving interviews with decision-makers about the potential uses of attribution science (e.g. Sippel et al. 2015).

One potential barrier in identifying applications for L\&D is that it is not yet clear exactly what actions to address losses and damages would entail, with different stakeholders holding different perspectives and priorities (Boyd et al. 2017; Fig. 5.1). Previous literature has already highlighted that the potential role for science in relation to L\&D might be different depending on what is meant by $L \& D$, and what L\&D mechanisms aim to do (Surminski and Lopez 2015; Huggel et al. 2015a; chapters by Lopez et al. 2018 and Schinko et al. 2018). Here we explore potential applications 
for attribution science in a L\&D context with a very broad view of what L\&D might signify, including a large range of actions to address losses and damages, as identified by different stakeholders (Boyd et al. 2017), for example adaptation, risk reduction, risk transfer, insurance, risk pooling, risk management, recovery, rehabilitation, and compensation.

\subsubsection{Catalysing Action}

Many papers, and stakeholder interviews, have highlighted an important role for attribution in catalysing action (Bouwer 2011; Surminski and Lopez 2015; Parker et al. 2017a). This refers to action in terms of greater mitigation ambition, as well as actions to better prepare for disasters. Stott and Walton (2013) highlight that attribution of extreme weather events could help aid agencies to encourage preparation for disasters, and research projects are now underway to develop attribution studies with DRR agencies to pilot such an approach (www.climatecentral.org). Promoting mitigation could also be seen as an important element in relation to L\&D. Several interviewees in the Boyd et al. (2017) study highlighted that one of the important goals of L\&D negotiations is to heighten ambition to mitigate, in order to avoid impacts and risks. If the interviewees and commentators are correct, that attribution evidence could motivate mitigation (see Parker et al. 2017a), presumably by demonstrating quantitative evidence and examples of how GHGs and aerosols are affecting people; this motivates further attribution research, and also further efforts to communicate the results in an understandable form for policy-makers and the public (following existing work e.g. wwa.climatecentral.org).

\subsubsection{Providing Evidence for Liability and Compensation}

The most frequently discussed applications of attribution science for L\&D arguably relate to liability and compensation (Allen 2003; Allen et al. 2007; Stone et al. 2009; Thompson and Otto 2015; Parker et al. 2016, 2017a; Thornton and Covington 2016). L\&D has its origins in calls from small islands states for some form of compensation for climate change impacts, particularly sea level rise (Mace and Verheyen 2016), and L\&D is sometimes still discussed with reference to some notion of a global compensation mechanism. In this context, attribution is often raised in terms of whether it could provide sufficient evidence for such a mechanism (e.g. Craeynest 2010). For example, one interviewee from Boyd et al. (2017)'s study explained: "In order to have a reliable L\&D compensation mechanism, you'll need to have a very high confidence about the causes of L\&D, if the science is not $100 \%$ or close, there'll always be room to contest" (see similar discussions in Parker et al. 2017a). For one stakeholder, attribution science was even described as the key to unlocking liability: "we don't have to enter the rooms on liability and compensation, those doors are 
locked behind a door called attribution. The key to that door lies with the scientific community, it is still being forged."

These interviews took place before the Paris Climate Conference, when the following text was included in Decision 1/CP. 21, referring to the article of the Paris Agreement about L\&D: "Article 8 of the Agreement does not involve or provide a basis for any liability or compensation;" (UNFCCC 2015, paragraph 51). Subsequent analysis suggests that this does not prevent liability or compensation per se, but rather only in connection with Article 8 (Mace and Verheyen 2016; Calliari 2016). It does not, for example, prevent actions outside the framework of the UNFCCC, such as legal action against individual countries or companies.

The potential for attribution evidence to support ad hoc litigation, outside of the UNFCCC, has also received considerable attention in the literature, with mixed views about whether the science would be strong enough to stand up in court (e.g. Farris 2009; Adam 2011; Wrathall et al. 2015; Hannart et al. 2016; Thornton and Covington 2016; see also the chapter by Simlinger and Mayer 2018).

Drawing on the review of available evidence in Sect. 5.3, it would seem that any form of liability and compensation which relies on a complete "causative chain" from monetary losses - to weather and climate-to anthropogenic climate change-to emitters, might currently struggle to find many examples with sufficient evidence. Given the progress of the science, such examples will however emerge, albeit with uncertainties (Otto et al. 2017). It will then become a legal question of whether and how these might support individual lawsuits. Existing analysis suggests that the requirements of quantitative evidence would be rather different, for example if the case is examined in tort law or in the context of human rights (Marjanac and Patton 2018).

Beyond ad hoc litigation, the idea of a global compensation mechanism based on fully attributable losses and damages is currently far from reality. This is not to say that some kind of global insurance and/or compensation mechanism is not possible, but rather that trying to base payments on quantitative attribution evidence at a local level is unlikely to lead to fair outcomes, as the strength of available evidence will vary between places and events. In fact, the evidence at the disposal of poor countries, typically highly vulnerable to climate change, is very limited as compared to richer countries with long-term and high-quality data series and information (Huggel et al. 2016b; Fig. 5.9). Several proposals for global insurance mechanisms in the context of L\&D have been developed (e.g. Linnerooth-Bayer et al. 2009; chapter by LinneroothBayer et al. 2018), ${ }^{28}$ and these have not necessarily required a full causative chain of attribution evidence (see also introduction by Mechler et al. 2018).

\footnotetext{
${ }^{28}$ The original proposal from the Alliance of Small Islands States for to establish a 'collective losssharing scheme' to 'compensate the most vulnerable small island and low-lying coastal developing countries for losses and damages' is described in Mace and Verheyen (2016), and can be found in an annex at http://unfccc.int/resource/docs/a/15_2.pdf.
} 


\subsubsection{Informing the Distribution of Adaptation or L\&D Funding}

Another frequent, and related, discussion about the potential use of attribution science concerns whether it might be applied to help inform distribution of adaptation or (potential) L\&D funding. Currently projects which seek support from the Green Climate Fund are judged against a list of criteria, for example expected reduction in vulnerability and ability to strengthen institutional capacity (the investment framework is documented in e.g. GCF 2015). It is conceivable that some kind of attribution evidence might be required as part such a checklist. In the context of L\&D, some have suggested a separate fund could be established for projects which seek to address losses and damages (e.g. Richards and Boom 2015). Such a fund would presumably also have a list of necessary criteria which could include attribution evidence. The concept of a L\&D fund is related to the idea of a global compensation mechanism, but here we discuss it separately, since it could, for example, be based on voluntary contributions, and it is perhaps useful to think about how evidence might be applied to distribute available funds rather than to extract new funding from emitters.

Several authors (Hoegh-Guldberg et al. 2011) and stakeholders interviewed (in Parker et al. 2017a; Sippel et al. 2015) have suggested that attribution science could be used to help allocate resources. However, others argue that, given disparities in the strength of evidence, it would be counterproductive or unfair to give priority only to projects which address impacts that can be confidently attributed to anthropogenic

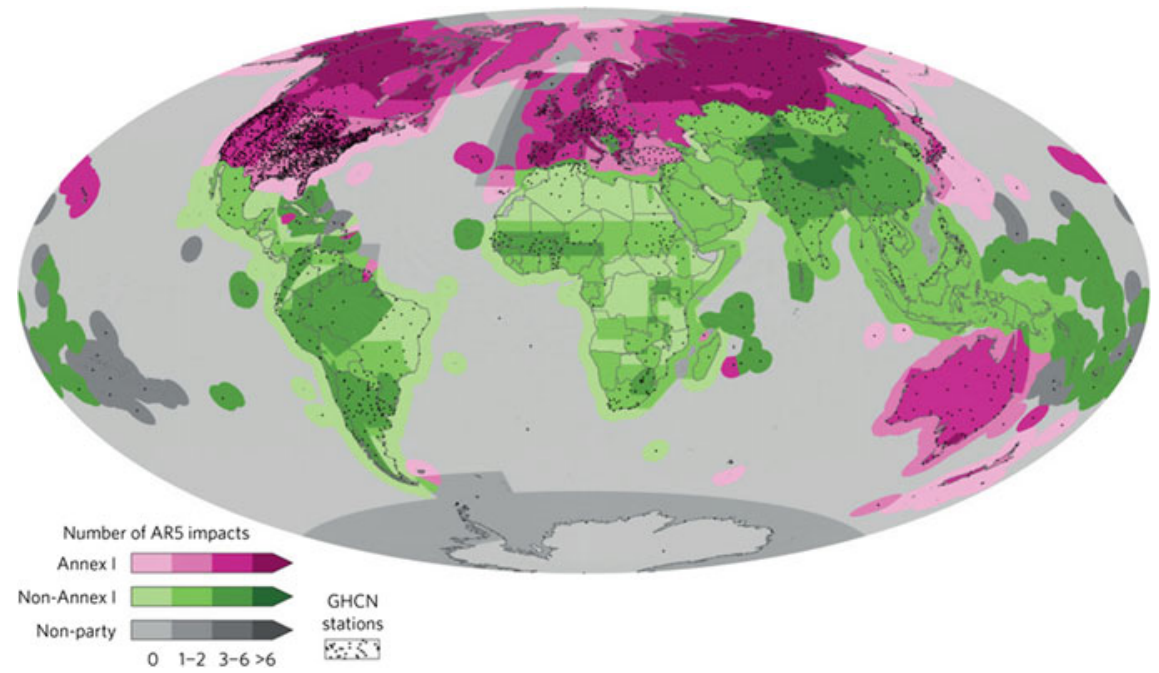

Fig. 5.9 Map demonstrating the location of weather stations in the Global Historical Climatology Network (black points), as well as the number of detected impacts reported in the IPCC AR5 for Annex I countries (in purple), Non-Annex I countries (in green), and regions not party to the UNFCCC (in grey). Source Huggel et al. (2016b) 
climate change (Hulme et al. 2011). Referring again to Fig. 5.9, it is clear that some countries and regions have more data available than others, and whilst this is not the only factor that determines confidence in attribution studies (Otto et al. 2013), the strength of evidence will continue to vary between regions, and between climate change impacts. The discussion about who is most deserving of funding raises ethical questions which cannot be answered by scientists, and highlights that incorporating attribution science into a system for distributing funding would not be straightforward. In the final section we explore a potentially less controversial, and perhaps more fundamental way in which the science can be used in helping to decide which actions might address losses and damages.

\subsubsection{Analysing Drivers of L\&D to Inform Practical Actions to Avert, Minimise, and Address Losses and Damages}

Rather than being used to help answer political and ethical questions about who should pay, and who should receive support (see chapter by Wallimann-Helmer et al. 2018), attribution science could instead help to answer practical questions about how to spend the money: How should risks be managed? What can be done to minimise and address losses and damages? Which actions can be taken to help people to recover from L\&D? In order to prepare for changing risks, it is fundamental to understand their causes, including drivers of changes in hazard, as well as vulnerability and exposure. Anthropogenic climate change is just one driver of changing hazard, but a fundamental driver which must be incorporated into risk analyses in order to identify risk management options which will be most effective in a changing climate (see Mechler and Schinko 2016; chapter by Schinko et al. 2018). As demonstrated in Sect. 5.3, attribution science is focused on establishing causality and, alongside other climate change research, is an important element in a toolkit for climate risk management.

From a climate risk management perspective, the key is to be able to quantify current risks and how these may evolve in the future in a changing climate (and, more broadly, a changing world). The importance of future climate model projections is frequently highlighted with reference to adaptation planning (e.g. Giorgi et al. 2009) and, more recently, with reference to planning to address losses and damages (Surminski and Lopez 2015). It is also increasingly recognised that, to understand risk, climate projections should be combined with projections of future changes in exposure and vulnerability (Mechler and Bouwer 2015). Attribution science can be a complementary source of evidence, which (a) provides important additional information about changing risk in the presence of uncertainty, (b) offers an assessment of how risks are changing now (whilst future projections might not be relevant for 30 years or more), and (c) helps to diagnose the causes of losses and damages, which could be useful in prioritising actions to reduce risk. The need to assess science investigating the role of climate and non-climate drivers in recent high-impact 
events, and how those drivers are changing across time and spatial scales, in order to inform adaptation and risk management, has been recognised as a key priority for the next IPCC report (RC/RCCC 2017). Here we give a few examples to illustrate the importance of this approach.

In East Africa, many climate models suggest that the region will become wetter in future (Shongwe et al. 2011; James et al. 2014b), which might imply the need to adapt to wetter conditions, and potential for losses and damages from extreme precipitation or flooding (Shongwe et al. 2011; Taylor et al. 2013). However, observations suggest that there has been a recent increase in drought (Rowell et al. 2015), and analysis of the climate processes associated with precipitation decline suggest it could be caused by warming of the Indian Ocean, which is expected under anthropogenic climate change (Copsey et al. 2006; Williams and Funk 2011; Williams et al. 2012). An attribution study of the drivers of the climate hazards that resulted in the extreme drought in 2010-11 (Lott et al. 2013) showed that it was influenced by both climate change and natural variability (with an important role for the El Nino Southern Oscillation). By combining evidence from attribution research with observational evidence, physical understanding, and future projections, it seems clear that adaptation and L\&D planning for East Africa should not assume wetter futures (Funk 2011), and should strengthen measures to respond to drought, which could continue to occur due to natural variability, and may be amplified by climate change.

Another reason that attribution research can provide important evidence to help address losses and damages, is that it offers an assessment of how risk is changing now. For many decision-makers, information about how climate might change in 30 years is not relevant because their planning horizons are much shorter (Jones et al. 2017). This is true for several of the approaches which have been suggested to address losses and damages. For example, there has been a great deal of emphasis on risk pooling schemes and (re)insurance. These systems rely on estimates of the probability of extreme weather events based on historical data, which may no longer be relevant in a changing climate. Attribution studies can provide an estimate of the current probability of extreme weather events. Finally, the above has focused on the hazard component of climate risk management but attribution science can also be extended to provide relevant information on the vulnerability and exposure components. This principle is demonstrated by considering the impact of different responses to two category 4 tropical cyclones in Mozambique (Benessene 2007; UNISDR 2010). This showed significantly less loss of life in a more recent event in 2007 compared to 2000, as a result of better early warning systems reducing human exposure to a hazard of similar magnitude. Another example by Otto et al. (2015b) showed that climate change had not altered the likelihood of the precipitation deficit associated with the 2014-15 droughts in the Sao Paolo area. Thus higher losses in this case compared to earlier events could not be attributed to a change in the hazard and so were attributable to higher vulnerability and exposure resulting from socio-economic changes. These examples demonstrate that attribution science can be useful to guide the design of improved future responses to climate-related risks. 


\subsection{Conclusions}

In this chapter we have discussed how attribution science might be useful for L\&D policy and practice. As has been widely recognised, the concept of L\&D from climate change is still vague and contested with a diverse range of perspectives held amongst stakeholders. This makes it challenging to say exactly what kind of scientific input is needed. Here we take a broad approach to consider how attribution science might be relevant to $L \& D$ discussions, and a range of possible options for $L \& D$ policy and practice. The first step was to examine the discourse surrounding L\&D and existing mentions of, and debates about, attribution in the L\&D policy space (Sect. 5.2). If scientists, practitioners, and policy-makers are to jointly integrate science into actions to address losses and damages, it is important to understand the baseline understandings and associations held by different stakeholders. We have followed policy discussions for a number of years, and directly asked many participants in L\&D discussions about their views on attribution, including through stakeholder interviews (Box 5.2). This research has demonstrated that attribution is a controversial but also recurring issue in $L \& D$ discussions. In our interviews with stakeholders and observations of meetings about L\&D, attribution was often mentioned. Few stakeholders demonstrated in-depth knowledge of attribution science, but they often raised questions about whether losses and damages could be attributed to climate change. These questions relate to practical issues about the mandate of the UNFCCC, but also have important political implications. Attribution is often mentioned alongside responsibility, blame and liability.

It therefore appears that attribution is a key issue of relevance to L $\& D$ discussions, but it is so far very difficult to discuss in detail how the science might be used, because it is considered to be a controversial topic. If scientists are to effectively engage in dialogue with policy-makers, it would be helpful for them to be aware of these associations and controversies; and also aware that policy-makers work in an environment where science is often used for political motives, and clarity is not always helpful or asked for. In fact, climate negotiators may be mandated to avoid certain topics or terminology. Communicating scientific results is therefore not sufficient to support policy: it must be communicated in a language that policymakers can work with. At the same time, it would be helpful if policy-makers and practitioners were made more aware of the findings and methodologies of attribution studies and the fact that attribution science itself is not primarily designed to establish responsibility. The political and ethical implications are far beyond the realm of physical scientists, and many scientists are keen to remain impartial purveyors of information, without becoming involved in politics: a potentially useful resource for policy-makers in a landscape where most actors do have political motives.

A more in-depth discussion between scientists, practitioners, and policy-makers about attribution science would likely reveal much that is relevant to averting and addressing losses and damages, regardless of political positions. As outlined in Sect. 5.3, there are a number of fields of inquiry that are advancing rapidly which could be integrated to better understand the influence of anthropogenic climate 
change on losses and damages, and how this compares with other drivers of risk. There are uncertainties, and the level of evidence available is not even between countries, regions, or between different climate change impacts. It may therefore be challenging to use attribution science for the kind of applications which are most frequently suggested. Notably it might be challenging to use attribution science for some kind of global compensation mechanism, or to allocate funding to address climate change impacts. Such systems might benefit from being informed by global estimates of attributable changes and evidence for the emergence of climate change impacts in different regions, rather than being informed by attribution studies for specific events or specific losses. However, as well as the difficult political and ethical questions about who should pay for losses and damages, and who deserves support to address losses and damages, there are also fundamental practical questions about how to help people prepare for, and recover from, climate change impacts and losses and damages. To address these questions most effectively, and manage risks in a changing climate, understanding drivers of risk is fundamental, and attribution science has a key role to play.

To end, how is attribution science relevant for $L \& D$ policy and practice? And could it be useful? While in a political context attribution is often associated with compensation for climate change impacts, we show that the science of attribution has the potential for much broader applications. Attribution has an important role to play in helping understanding $L \& D$, including through quantification of risks, investigating of the relative importance of different drivers of change, and identifying timescales on which significant impacts of climate change emerge in different regions of the world. Regardless of the policy mechanisms for addressing losses and damages, it is important to foster a better understanding of how climate change is influencing losses and damages. With further scientific integration, including integrating attribution studies with future projections, and through informed sciencepolicy-practice dialogue, attribution could contribute towards the development of useful practical actions to avert and address losses and damages.

\section{References}

Adam D (2011) Climate change in court. Nat Clim Change 1(3):127. https://doi.org/10.1038/ncl imate 1131

Allen M (2003) Liability for climate change. Nature 421:891-892. https://doi.org/10.1038/421891a

Allen M, Pall P, Stone D, Stott P, Frame D, Min S-K, Nozawa T, Yukimoto S (2007) Scientific challenges in the attribution of harm to human influence on climate. University of Pennsylvania Law Rev 1353-1400

Arnell N, Compagnucci L, Cunha R, da L, Hanaki K, Howe C, Shiklomanov GM SEI (2001) Hydrology and water resources. In: McCarthy J, Canziani O, Leary N, Dokken DWK (eds) Climate change 2001: impacts, adaptation and vulnerability. Contribution of working group II to the third assessment report of the intergovernmental panel on climate change. Cambridge University Press, Cambridge, United Kingdom and New York, NY, USA, pp 192-233 
Barnett TP, Pierce DW, Hidalgo HG, Bonfils C, Santer BD, Das T, Bala G, Wood AW, Nozawa T, Mirin AA, Cayan DR, Dettinger MD (2008) Human-Induced changes in the hydrology of the Western United States. Science 319:1080-1083

Benessene MV (2007) Experience in coping with floods in Central Mozambique. http://www.iisd. org/pdf/2007/climate_early_moises_benessene.pdf. Accessed 12 Jun 2010

Bindoff NL, Stott PA, AchutaRao KM, Allen MR, Gillett N, Gutzler D, Hansingo K, Hegerl G, Hu Y, Jain $S$ et al (2013) Detection and attribution of climate change: from global to regional. In: Stocker TF, Qin D, Plattner G-K et al (eds) Climate change 2013: the physical science basis. contribution of working group I to the fifth assessment report of the intergovernmental panel on climate change. Cambridge University Press, Cambridge, United Kingdom and New York, NY, USA, pp 867-952

Blaikie P, Cannon T, Davis I, Wisner B (2014) From event analysis to global lessons: disaster forensics for building resilience. Routledge, New York

Bouwer LM (2011) Have disaster losses increased due to anthropogenic climate change? Bull Am Meteor Soc 92:39-46. https://doi.org/10.1175/2010BAMS3092.1

Botzen W, Bouwer LM, Scussolini P, Kuik O, Haasnoot M, Lawrence J, Aerts JCJH (2018) Integrated disaster risk management and adaptation. In: Mechler R, Bouwer L, Schinko T, Surminski S, Linnerooth-Bayer J (eds) Loss and damage from climate change. Concepts, methods and policy options. Springer, Cham, pp 287-315

Boyd E, James R, Jones R (2016) Policy brief: a spectrum of views on loss and damage. http:// www.eci.ox.ac.uk/publications/161101.pdf

Boyd E, James RA, Jones RG, Young HR, Otto FE (2017) A typology of loss and damage perspectives. Nat Clim Change 7:723. https://doi.org/10.1038/nclimate3389

Bouwer LM (2018) Observed and projected impacts from extreme weather events: implications for loss and damage. In: Mechler R, Bouwer L, Schinko T, Surminski S, Linnerooth-Bayer J (eds) Loss and damage from climate change. Concepts, methods and policy options. Springer, Cham, pp 63-82

Calliari E (2016) Loss and damage: a critical discourse analysis of Parties' positions in climate change negotiations. J Risk Res 9877:1-23. https://doi.org/10.1080/13669877.2016.1240706

Calliari E, Surminski S, Mysiak J (2018) Politics of (and behind) the UNFCCC's loss and damage mechanism. In: Mechler R, Bouwer L, Schinko T, Surminski S, Linnerooth-Bayer J (eds) Loss and damage from climate change. Concepts, methods and policy options. Springer, Cham, pp 155-178

Christidis N, Stott PA, Zwiers FW, Shiogama H, Nozawa T (2010) Probabilistic estimates of recent changes in temperature: a multi-scale attribution analysis. Clim Dyn 34:1139-1156. https://do i.org/10.1007/s00382-009-0615-7

Christidis N, Stott PA, Scaife AA et al (2013) A new HADGEM3-a-based system for attribution of weather- and climate-related extreme events. J Clim 26:2756-2783. https://doi.org/10.1175/ JCLI-D-12-00169.1

Church JA, Monselesan D, Gregory JM, Marzeion B (2013) Evaluating the ability of process based models to project sea-level change. Environ Res Lett 8:14051. https://doi.org/10.1088/1748-93 26/8/1/014051

Clayton S, Manning CM, Krygsman K, Speiser M (2017) Mental health and our changing climate: impacts, implications, and guidance. American Psychological Association, and ecoAmerica: Washington, DC

Copsey D, Sutton R, Knight JR (2006) Recent trends in sea level pressure in the Indian Ocean region. Geophys Res Lett 33:L19712. https://doi.org/10.1029/2006GL027175

Craeynest L (2010) Loss and damage from climate change: the cost for poor people in developing countries. Action Aid International Discussion Paper

Cramer W, Yohe GW, Auffhammer M, Huggel C, Molau U, Dias MAF, Leemans R (2014) Detection and attribution of observed impacts. In: Field CB, Barros VR, Dokken DJ, Mach KJ, Mastrandrea MD, Bilir TE, Chatterjee M, Ebi KL, Estrada YO, Genova RC, Girma B, Kissel ES, Levy AN, MacCracken S, Mastrandrea PR, White LL (eds) Climate change 2014: impacts, adaptation, and vulnerability. Part A: global and sectoral aspects. Contribution of working group 
II to the fifth assessment report of the intergovernmental panel of climate change. Cambridge University Press, Cambridge, United Kingdom and New York, NY, USA, pp 979-1037

den Elzen M, Fuglestvedt J, Höhne N, Trudinger C, Lowe J, Matthews B, Romstad B, de Campos CP, Andronova N (2005) Analysing countries' contribution to climate change: scientific and policy-related choices. Environ Sci Policy 8:614-636. https://doi.org/10.1016/j.envsci.200 5.06.007

DesInventar (2015) DesInventar Online Edition 2013. In: Inventar. Desastr. Dispon. https://www. desinventar.net/

Dole R, Hoerling M, Perlwitz J, Eischeid J, Pegion P, Zhang T, Quan X-W, Xu T, Murray D (2011) Was there a basis for anticipating the 2010 Russian heat wave? Geophys Res Lett 38:1-5. https:// doi.org/10.1029/2010GL046582

Erikson KT (1976) Everything in its path. Simon and Schuster, New York

Farris M (2009) Compensating climate change victims: the climate compensation fund as an alternative to tort litigation. Sea Grant Law Policy 2:49-62

Folland CK, Colman AW, Smith DM, Boucher O, Parker DE, Vernier J-P (2013) High predictive skill of global surface temperature a year ahead. Geophys Res Lett 40:761-767. https://doi.org/ 10.1002/grl.50169

Foster G, Rahmstorf S (2011) Global temperature evolution 1979-2010. Environ Res Lett 6:44022. https://doi.org/10.1088/1748-9326/6/4/044022

Frame D, Joshi M, Hawkins E, Harrington LJ, de Roiste M (2017) Population-based emergence of unfamiliar climates. Nat Clim Change. https://doi.org/10.1038/NCLIMATE3297

Fuglestvedt J, Berntsen T, Myhre G, Rypdal K, Skeie RB (2008) Climate forcing from the transport sectors. Proc Natl Acad Sci 105:454-458. https://doi.org/10.1073/pnas.0702958104

Fuglestvedt JS, Kallbekken S (2015) Climate responsibility: fair shares? Nat Clim Change. https:// doi.org/10.1038/nclimate2791

Funk C (2011) We thought trouble was coming. Nature 476:7

Fyfe JC, Gillett NP, Thompson DWJ (2010) Comparing variability and trends in observed and modelled global-mean surface temperature. Geophys Res Lett 37. https://doi.org/10.1029/2010 g1044255

Gall M, Borden KA, Cutter SL (2009) When do losses count? Bull Am Meteor Soc 90:799-809. https://doi.org/10.1175/2008BAMS2721.1

Gardiner SM (2004) Ethics and global climate change. Ethics 114:555-600. https://doi.org/10.10 $86 / 382247$

GCF (2015) Decisions of the board — ninth meeting of the board, 24-26 March 2015, GCF/B.09/23

Giorgi F, Jones C, Asrar GR (2009) Addressing climate information needs at the regional level: the CORDEX framework. World Meteorological Organization (WMO) Bulletin 58:175-183

Gitay H, Brown S, Easterling W, Jallow B, Antle J, Apps M, Beamish R, Chapin T, Cramer W, Frangi JLJ (2001) Ecosystems and their goods and services. In: McCarthy J, Canziani O, Leary N, Dokken DWK (eds) Climate change 2001: impacts, adaptation and vulnerability. Contribution of working group II to the third assessment report of the intergovernmental panel on climate change. Cambridge University Press, Cambridge, United Kingdom and New York, NY, USA, pp 235-342

Guha-Sapir D, Below R, Hoyois P (2009) EM-DAT: The CRED/OFDA international disaster database. In: Cent. Res. Epidemiol. Disasters (CRED), Univ. Cathol. Louvain

Hannart A, Pearl J, Otto FEL, Naveau P, Ghil M (2016) Causal counterfactual theory for the attribution of weather and climate-related events. Bull Am Meteor Soc 97:99-110. https://doi. org/10.1175/BAMS-D-14-00034.1

Hansen G (2015) The evolution of the evidence base for observed impacts of climate change. Curr Opin Environ Sustain 14:187-197. https://doi.org/10.1016/j.cosust.2015.05.005

Hansen G, Cramer W (2015) Global distribution of observed climate change impacts. Nat Clim Change 5:182-185. https://doi.org/10.1038/nclimate2529

Hansen G, Stone D (2016) Assessing the observed impact of anthropogenic climate change. Nat Clim Change 6:532-537. https://doi.org/10.1038/nclimate2896 
Hansen G, Stone D, Auffhammer M, Huggel C, Cramer W (2016) Linking local impacts to changes in climate: a guide to attribution. Reg Environ Change 16:527-541. https://doi.org/10.1007/s10 113-015-0760-y

Heede R (2014) Tracing anthropogenic carbon dioxide and methane emissions to fossil fuel and cement producers, 1854-2010. Clim Change 122:229-241. https://doi.org/10.1007/s10584-01 3-0986-y

Hegerl GC, Zwiers FW, Braconnot P, Gillett NP, Luo Y, Marengo Orsini JA, Nicholls N, Penner JE, Stott PA (2007) Understanding and attributing climate change. In: Solomon SD, Qin M, Manning Z, Chen M, Marquis KB, Averyt MT, Miller HL (eds) Climate change 2007: the physical science basis. Contribution of working group I to the fourth assessment report of the intergovernmental panel on climate change. Cambridge University Press, Cambridge, United Kingdom and New York, NY, USA

Hegerl G, Hoegh-Guldberg O, Casassa G, Hoerling MP, Kovats RS, Parmesan C, Pierce DW, Stott PA (2010) Good practice guidance paper on detection and attribution related to anthropogenic climate change. In: Stocker T, Field C, Dahe Q et al (eds) Meeting report: IPCC expert meeting on detection and attribution related to anthropogenic climate change

Hegerl G, Zwiers F (2011) Use of models in detection and attribution of climate change. Wiley Interdisc Rev: Clim Change 2:570-591. https://doi.org/10.1002/wcc.121

Herring S, Hoerling M, Peterson T, Stott P (2014) Explaining extreme events of 2013 from a climate perspective. Bull Am Meteor Soc 95(9):S1-S96

Herring SC, Hoerling MP, Kossin JP, Peterson TC, Stott PA (2015) Explaining extreme events of 2014 from a climate perspective. Bull Am Meteor Soc 96:S1-S172. https://doi.org/10.1175/BA MS-D-15-00157.1

Herring SC, Christidis N, Hoell A, Kossin JP, Schreck CJ, Stott PA (eds) (2018) Explaining extreme events of 2016 from a climate perspective. Bull Amer Meteor Soc 99(1):S1-S157

Herring SC, Hoell A, Hoerling MP, Kossin JP, Schreck CJ III, Stott PA (2016) Explaining extreme events of 2015 from a climate perspective. Bull Am Meteor Soc 97:1-145

Hoegh-Guldberg O, Hegerl G, Root T, Zwiers F, Statt P, Pierce D, Allen M (2011) Difficult but not impossible. Nat Clim Change 1:72-72. https://doi.org/10.1038/nclimate1107

Huggel C, Stone D, Auffhammer M, Hansen G (2013) Loss and damage attribution. Nat Clim Change 3:694-696. https://doi.org/10.1038/nclimate1961

Huggel C, Stone D, Eicken H, Hansen G (2015a) Potential and limitations of the attribution of climate change impacts for informing loss and damage discussions and policies. Clim Change 133:453-467. https://doi.org/10.1007/s10584-015-1441-z

Huggel C, Raissig A, Rohrer M, Romero G, Diaz A, Salzmann N (2015b) How useful and reliable are disaster databases in the context of climate and global change? A comparative case study analysis in Peru. Nat Hazards Earth Sys Sci 15:475-485. https://doi.org/10.5194/nhess-15-475-2015

Huggel C, Bresch D, Hansen G, James R, Mechler R, Stone D, Wallimann-Helmer I (2016a) Attribution of irreversible loss to anthropogenic climate change. EGU General Assembly Conference 2016, held 17-22 April 2016 Vienna Austria, p 8557 18:8557

Huggel C, Wallimann-Helmer I, Stone D, Cramer W (2016b) Reconciling justice and attribution research to advance climate policy. Nat Clim Change 6:901-908. https://doi.org/10.1038/nclim ate 3104

Hulme M, O'Neill SJ, Dessai S (2011) Is weather event attribution necessary for adaptation funding? Science 334:764-765. https://doi.org/10.1126/science.1211740

IPCC (2012) Managing the risks of extreme events and disasters to advance climate change adaptation. A special report of working groups I and II of the intergovernmental panel on climate change. In: Field CB, Barros V, Stocker TF, Qin D, Dokken DJ, Ebi KL, Mastrandrea MD, Mach KJ, Plattner G-K, Allen SK, Tignor M, Midgley PM (eds). Cambridge University Press, Cambridge, UK, and New York, NY, USA

IPCC (2013) Climate change 2013: the physical science basis. contribution of working group I to the fifth assessment report of the intergovernmental panel on climate change. In: Stocker TF, Qin 
D, Plattner G-K, Tignor M, Allen SK, Boschung J, Nauels A, Xia Y, Bex V, Midgley PM (eds). Cambridge University Press, Cambridge, United Kingdom and New York, NY, USA, 1535 pp

IPCC (2014) Climate change 2014: synthesis report. Contribution of Working Groups I, II and III to the fifth assessment report of the intergovernmental panel on climate change. In: Core Writing Team RK, Pachauri, Meyer LA (eds). IPCC, Geneva, Switzerland, 151 pp

James R, Otto F, Parker H, Boyd E, Cornforth R, Mitchell D, Allen M (2014a) Characterizing loss and damage from climate change. Nat Clim Change 4:938-939. https://doi.org/10.1038/nclimate2411

James R, Washington R, Rowell DP (2014b) African climate change uncertainty in perturbed physics ensembles: implications of global warming to $4{ }^{\circ} \mathrm{C}$ and beyond. J Clim 27:4677-4692. https://doi.org/10.1175/JCLI-D-13-00612.1

Jones LM, Bernknopf R, Cox D et al (2008) The shakeout scenario. US Geol Survey Open-File Report 1150:308

Jones L, Champalle C, Chesterman S, Cramer L, Crane TA (2017) Constraining and enabling factors to using long-term climate information in decision-making. Clim Policy 17:551-572. https://doi.org/10.1080/14693062.2016.1191008

Jongman B, Winsemius HC, Aerts JCJH, Coughlan de Perez E, Van Aalst MK, Kron W, Ward PJ (2015) Declining vulnerability to river floods and the global benefits of adaptation. Proc Natl Acad Sci USA 112(18):E2271-E2280

Kay AL, Crooks SM, Pall P, Stone DA (2011) Attribution of Autumn/Winter 2000 flood risk in England to anthropogenic climate change: a catchment-based study. J Hydrol 406:97-112. https://doi.org/10.1016/j.jhydrol.2011.06.006

Keating A, Venkateswaran K, Szoenyi M, MacClune K, Mechler R (2016) From event analysis to global lessons: disaster forensics for building resilience. Nat Hazards Earth Sys Sci 16:1603-1616. https://doi.org/10.5194/nhess-16-1603-2016

Kreibich H, Di Baldassarre G, Vorogushyn S, Aerts JCJH, Apel H, Aronica GT, Arnbjerg-Nielsen K, Bouwer LM, Bubeck P, Caloiero T (2017) Adaptation to flood risk: results of international paired flood event studies. Earth's Future. https://doi.org/10.1002/2017EF000606

Kron W, Steuer M, Löw P, Wirtz A (2012) How to deal properly with a natural catastrophe database-analysis of flood losses. Nat Hazards Earth Sys Sci 12:535-550. https://doi.org/10.5 194/nhess-12-535-2012

Lee D, Min S-K, Park C, Suh M-S, Ahn J-B, Cha D-H, Lee D-K, Hong S-Y, Park S-C, Kang H-S (2016) Time of emergence of anthropogenic warming signals in the Northeast Asia assessed from multi-regional climate models. Asia-Pacific J Atmos Sci 52:129-137. https://doi.org/10.1 007/s13143-016-0014-z

Linnerooth-Bayer J, Warner K, Bals C, Hoppe P, Burton I, Loster T, Haas A (2009) Insurance, developing countries and climate change. Geneva Papers in Risk Insurance-Issues and Practice 34:381-400. https://doi.org/10.2307/41953037

Linnerooth-Bayer J, Surminski S, Bouwer LM, Noy I and R Mechler (2018) Insurance as a response to loss and damage? In: Mechler R, Bouwer L, Schinko T, Surminski S, Linnerooth-Bayer J (eds) Loss and damage from climate change. Concepts, methods and policy options. Springer, Cham, pp 483-512

Lopez A, Surminski S, Serdeczny O (2018) The role of the physical sciences in loss and damage decision-making. In: Mechler R, Bouwer L, Schinko T, Surminski S, Linnerooth-Bayer J (eds) Loss and damage from climate change. Concepts, Methods and policy options. Springer, Cham, pp 261-285

Lott FC, Christidis N, Stott PA (2013) Can the 2011 East African drought be attributed to humaninduced climate change? Geophys Res Lett 40:1177-1181. https://doi.org/10.1002/grl.50235

Mace MJ, Verheyen R (2016) Loss, damage and responsibility after COP21: all options open for the Paris agreement. Rev Eur Compar Int Environ Law 25:197-214. https://doi.org/10.1111/re el. 12172

Marjanac S, Patton L (2018) Extreme weather event attribution science and climate change litigation: an essential step in the causal chain? J Energy Nat Res Law. https://doi.org/10.1080/ 02646811.2018 .1451020 
Marthews TR, Otto FEL, Mitchell D, Dadson SJ, Jones RG (2015) The 2014 drought in the horn of Africa: attribution of meteorological drivers. In: Herring SC, Hoerling MP, Kossin JP et al (eds) Explaining extreme events of 2014 from a climate perspective. Bulletin of the American Meteorological Society

Marzeion B, Cogley JG, Richter K, Parkes D (2014) Attribution of global glacier mass loss to anthropogenic and natural causes. Science 345:919-921. https://doi.org/10.1126/science.125 4702

Matthews HD (2016) Quantifying historical carbon and climate debts among nations. Nat Clim Change 6:60-64. https://doi.org/10.1038/NCLIMATE2774

Mechler R, Bouwer LM (2015) Understanding trends and projections of disaster losses and climate change: is vulnerability the missing link? Clim Change 133:23-35. https://doi.org/10.1007/s10 584-014-1141-0

Mechler R, Schinko T (2016) Identifying the policy space for climate loss and damage. Science (80-)354:290-292

Mechler R et al (2018) Science for loss and damage. Findings and propositions. In: Mechler R, Bouwer L, Schinko T, Surminski S, Linnerooth-Bayer J (eds) Loss and damage from climate change. Concepts, methods and policy options. Springer, Cham, pp 3-37

Meehl GA (2005) How much more global warming and sea level rise? Science 307:1769-1772. https://doi.org/10.1126/science.1106663

Mitchell D, Heaviside C, Vardoulakis S, Huntingford C, Masato G, Guillod BP, Frumhoff P, Bowery A, Wallom D, Allen M (2016) Attributing human mortality during extreme heat waves to anthropogenic climate change. Environ Res Lett 11:74006. https://doi.org/10.1088/1748-932 $6 / 11 / 7 / 074006$

Mitchell JFB, Karoly DJ Hegerl GC, Zwiers FW, Allen MR, Marengo J (2001) Detection of climate change and attribution of causes. Climate change 2001: The scientific basis. Cambridge University Press, Cambridge, United Kingdom and New York, NY, USA, pp 697-738

Mitchell JK (1999) Megacities and natural disasters: a comparative analysis. GeoJournal 49:137-142. https://doi.org/10.1023/A:1007024703844

Muller B, Hohne N, Ellerman C (2009) Differentiating (historic) responsibilities for climate change. Clim Policy 9:593-611. https://doi.org/10.3763/cpol.2008.0570

National Academies of Sciences, Engineering and Medicine (2016) Attribution of extreme weather events in the context of climate change. National Academies Press: Washington, D.C. https://d oi.org/10.17226/21852

Oliver-Smith A, Hoffman SM (1999) The angry earth: disaster in anthropological perspective. Routledge, New York

Otto FEL, Massey N, Van Oldenborgh GJ, Jones RG, Allen MR (2012) Reconciling two approaches to attribution of the 2010 Russian heat wave. Geophys Res Lett 39:1-5. https://doi.org/10.1029/ 2011GL050422

Otto FEL, Jones RG, Halladay K, Allen MR (2013) Attribution of changes in precipitation patterns in African rainforests. Philos Trans Royal Soc Londin B: Biol Sci 368:20120299-20120299. https://doi.org/10.1098/rstb.2012.0299

Otto FEL, Boyd E, Jones RG, Cornforth RJ, James R, Parker HR, Allen MR (2015a) Attribution of extreme weather events in Africa: a preliminary exploration of the science and policy implications. Clim Change 132:531-543. https://doi.org/10.1007/s10584-015-1432-0

Otto FEL, Coelho C a. S, King A, et al (2015b) Factors other than climate change, main drivers of 2014/5 water shortage in southeast Brazil. In: Herring SC, Hoerling MP, Kossin JP et al (eds) Explaining extreme events of 2014 from a climate perspective. Bull Am Meteorol Soc 96:35-40

Otto FEL, van Oldenborgh GJ, Eden J, Stott PA, Karoly DJ, Allen MR (2016) The attribution question. Nature. Clim Change 6:813-816. https://doi.org/10.1038/nclimate3089

Otto FEL, Skeie RB, Fuglestvedt JS, Bernsten T, Allen MR (2017) Assigning historical responsibilities for extreme weather events. Nat Clim Change 7:757-759. https://doi.org/10.1038/nclim ate 3419 
Pall P, Aina T, Stone DA, Stott PA, Nozawa T, Hilberts AGJ, Lohman D, Allen MR (2011) Anthropogenic greenhouse gas contribution to flood risk in England and Wales in autumn 2000. Nature 470:382-385. https://doi.org/10.1038/nature09762

Parker D, Folland C, Scaife A, Knight J, Colman A, Baines P, Dong B (2007) Decadal to multidecadal variability and the climate change background. J Geophys Res Atmos 112:1-18. https://doi.org/10.1029/2007JD008411

Parker HR, Cornforth RJ, Boyd E, James R, Otto FE, Allen MR (2015) Implications of event attribution for loss and damage policy. Weather 70:268-272. https://doi.org/10.1002/wea.2540

Parker HR, Cornforth RJ, Suarez P et al (2016) Using a game to engage stakeholders in extreme event attribution science. Int J Disaster Risk Sci 7:353-365. https://doi.org/10.1007/s13753-016-0105-6

Parker HR, Boyd E, Cornforth RJ, James R, Otto FE, Allen MR (2017a) Stakeholder perceptions of event attribution in the loss and damage debate. Clim Policy 17:533-550. https://doi.org/10. 1080/14693062.2015.1124750

Parker HR, Lott FC, Cornforth RJ, Mitchell DM, Sparrow S, Wallom D (2017b) A comparison of model ensembles for attributing 2012 West African rainfall. Environ Res Lett 12:14019. https:// doi.org/10.1088/1748-9326/aa5386

Peterson TC, Stott PA, Herring S (2012) Explaining extreme events of 2011 from a climate perspective. Bull Am Meteorol Soc 93:1041-1067. https://doi.org/10.1175/BAMS-D-12-00021.1

Peterson T, Stott P, Herring S (2013) Explaining extreme events of 2012 from a climate perspective. Bull Am Meteorol Soc 94:1-74

Rahmstorf S, Coumou D (2011) Increase of extreme events in a warming world. Proc Natl Acad Sci 108:17905-17909. https://doi.org/10.1073/pnas.1101766108

RC/RCCC (2017) Bridging science, policy and practice; report of the international conference on climate risk management-pre-scoping meeting for the IPCC sixth assessment report (5-7 April 2017, Nairobi)

Richards J-A, Boom K (2015) Big oil, coal and gas producers paying for their climate damage

Rosenzweig C, Karoly D, Vicarelli M, Neofotis P, Qigang Wu, Casassa G, Menzel A, Root TL, Estrella N, Seguin B (2008) Attributing physical and biological impacts to anthropogenic climate change. Nature 453:353-357. https://doi.org/10.1038/nature06937

Rowell DP, Booth BBB, Nicholson SE, Good P (2015) Reconciling past and future rainfall trends over East Africa. J Clim 28:9768-9788. https://doi.org/10.1175/JCLI-D-15-0140.1

Santer BD, Mears C, Wentz FJ, Taylor KE, Gleckler PJ, Wigley TML, Barnett TP, Boyle JS, Bruggemann W, Gillet NP (2007) Identification of human-induced changes in atmospheric moisture content. Proc Natl Acad Sci 104:15248-15253. https://doi.org/10.1073/pnas.0702872104

Santer BD, Wigley TML, Barnett TP, Anyamba E (1995) Detection of climate change and attribution of causes. In: Houghton JT, Meira Filho LG, Callander BA et al (eds) Climate change 1995: the science of climate change. Contribution of working group I to the second assessment report of the intergovernmental panel on climate change. Cambridge University Press, Cambridge, United Kingdom and New York, NY, USA

Schaller N, Kay AL, Lamb R, Massey NR, van Oldenborgh GJ, Otto FEL, Sparrow SN, Vautard R, Yiou P, Ashpole I, Bowery A, Crooks SM, Haustein K, Huntingford C, Ingram WJ, Jones RG, Legg T, Miller J, Skeggs J, Wallom D, Weisheimer A, Wilson S, Stott PA, Allen MR (2016) Human influence on climate in the 2014 southern England winter floods and their impacts. Nat Clim Change 6:627-634. https://doi.org/10.1038/nclimate2927

Schinko T, Mechler R, Hochrainer-Stigler S (2018) The risk and policy space for loss and damage: integrating notions of distributive and compensatory justice with comprehensive climate risk management. In: Mechler R, Bouwer L, Schinko T, Surminski S, Linnerooth-Bayer J (eds) Loss and damage from climate change. Concepts, methods and policy options. Springer, Cham, pp 83-110

Serdeczny O, Waters E, Chan S (2016) Non-economic loss and damage in the context of climate change: understanding the challenges. German Development Institute No. 03/16: Berlin

Serdeczny O (2018) Non-economic loss and damage and the warsaw international mechanism. In: Mechler R, Bouwer L, Schinko T, Surminski S, Linnerooth-Bayer J (eds) Loss and damage from climate change. Concepts, methods and policy options. Springer, Cham, pp 205-220 
Shongwe ME, van Oldenborgh GJ, van den Hurk B, van Aalst M (2011) Projected changes in mean and extreme precipitation in Africa under global warming. Part II: East Africa. J Clim 24:3718-3733. https://doi.org/10.1175/2010JCLI2883.1

Simlinger F, Mayer B (2018) Legal responses to climate change induced loss and damage. In: Mechler R, Bouwer L, Schinko T, Surminski S, Linnerooth-Bayer J (eds) Loss and damage from climate change. Concepts, methods and policy options. Springer, Cham, pp 179-203

Sippel S, Walton P, Otto FEL (2015) Stakeholder perspectives on the attribution of extreme weather events: an explorative enquiry. Weather Clim Soc 7:224-237. https://doi.org/10.1175/WCASD-14-00045.1

Sippel S, El-Madany TS, Migliavacca M, Mehecha MD, Carrara A, Flach M, Kaminski T, Otto FEL, Tonicke K, Reichstein M (2018) Response in ecosystem functioning on the Iberian Peninsula. Bull Am Meteorol Soc 99:S80-S85. https://doi.org/10.1175/BAMS-D-17-0135.1

Skeie RB, Fuglestvedt J, Berntsen T, Peters GP, Andrew R, Allen M, Kallbekken S (2017) Perspective has a strong effect on the calculation of historical contributions to global warming. Environ Res Lett 12:24022. https://doi.org/10.1088/1748-9326/aa5b0a

Stone DA, Allen MR, Stott PA, Pall P, Min SK, Nozawa T, Yukimoto S (2009) The detection and attribution of human influence on climate. Ann Rev Environ Res 34:1-16. https://doi.org/10.11 46/annurev.environ.040308.101032

Stone D, Auffhammer M, Carey M, Hansen G, Huggel C, Cramer W, Lobell D, Molau U, Solow A, Tibig L (2013) The challenge to detect and attribute effects of climate change on human and natural systems. Clim Change 121:381-395. https://doi.org/10.1007/s10584-013-0873-6

Stone DA, Allen MR (2005) The end-to-end attribution problem: from emissions to impacts. Clim Change 71:303-318. https://doi.org/10.1007/s10584-005-6778-2

Stone DA, Hansen G (2016) Rapid systematic assessment of the detection and attribution of regional anthropogenic climate change. Clim Dyn 47:1399-1415. https://doi.org/10.1007/s003 82-015-2909-2

Stott PA, Tett SFB, Jones GS, Allen MR, Mitchell JFB, Jenkins GJ (2000) External control of 20th century temperature by natural and anthropogenic forcings. Science 290:2133-2137. https://do i.org/10.1126/science.290.5499.2133

Stott P, Walton P (2013) Attribution of climate-related events: understanding stakeholder needs. Weather. https://doi.org/10.1002/wea.2152

Stott PA, Christidis N, Otto FEL, Sun Y, Vanderlinden J-P, van Oldenborgh GJ, Vautard R, von Storch H, Walton P, Yiou P (2016) Attribution of extreme weather and climate-related events. Wiley Interdisc Rev: Clim Change 7:23-41. https://doi.org/10.1002/wcc.380

Surminski S, Lopez A (2015) Concept of loss and damage of climate change-a new challenge for climate decision-making? A climate science perspective. Clim Develop 7:267-277. https:// doi.org/10.1080/17565529.2014.934770

Taylor RG, Todd MC, Kongola L, Maurice L, Nahozya E, Hosea Sanga, MachDonald AM (2013) Evidence of the dependence of groundwater resources on extreme rainfall in East Africa. Nat Clim Change 3:374-378. https://doi.org/10.1038/nclimate1731

Tett SF, Stott PA, Allen MR, Ingram WJ, Mitchell JF (1999) Causes of twentieth-century temperature change near the Earth's surface. Nature 399:569-572. https://doi.org/10.1038/21164

Thompson A, Otto FEL (2015) Ethical and normative implications of weather event attribution for policy discussions concerning loss and damage. Clim Change 133:439-451. https://doi.org/10. 1007/s10584-015-1433-Z

Thornton J, Covington H (2016) Climate change before the court. Nat Geosci 9:3-5. https://doi.o $\mathrm{rg} / 10.1038 /$ ngeo 2612

Trenberth KE, Fasullo JT, Shepherd TG (2015) Attribution of climate extreme events. Nat Clim Change 5:725-730. https://doi.org/10.1038/nclimate2657

Uhe P, Sjoukje P, Kew S, Shah K, Otto F, van Oldenborgh GJ, Singh R, Arrighi J, Cullen H (2017) Kenya Drought, 2016-World Weather Attribution. https://wwa.climatecentral.org/analyses/ke nya-drought-2016/ Accessed 13 Jun 2017 
UN (1992) The United Nations framework convention on climate change. United Nations, Rio de Janeiro. https://unfccc.int/resource/docs/convkp/conveng.pdf

UNEP (2016) Loss and Damage: The Role of Ecosystem Services. Nairobi, Kenya. https://unepl ive.unep.org/media/docs/assessments/loss_and_damage.pdf

UNFCCC (2011) Decision 1/CP.16 The Cancun agreements: outcome of the work of the ad hoc working group on long-term cooperative action under the convention

UNFCCC (2013) Decision 2/CP.19: Warsaw international mechanism for loss and damage associated with climate change impacts

UNFCCC (2015) Adoption of the Paris agreement. FCCC/CP/2015/10/Add.1. Paris, France

UNISDR (2010) Guidance note on recovery: governance, International Recovery Platform \& United Nations Development Programme India. https://www.unisdr.org/we/inform/publication s/16774 Accessed 13 Jun 2017

van der Wiel K, Kapnick SB, van Oldenborgh GJ, Whan K, Philip S, Vecchi GA, Singh RK, Arrighi J, Cullen H (2017) Rapid attribution of the August 2016 flood-inducing extreme precipitation in south Louisiana to climate change. Hydrol Earth Syst Sci 21:897-921. https://doi.org/10.5194/ hess-21-897-2017

Vanhala L, Hestbaek C (2016) Framing loss and damage in the UNFCCC negotiations: the struggle over meaning and the Warsaw international mechanism. Global Environ Politics 16:111-129. https://doi.org/10.1162/GLEP_a_00379

Wallimann-Helmer I, Meyer L, Mintz-Woo K, Schinko T, Serdeczny O (2018) Ethical challenges in the context of climate loss and damage. In: Mechler R, Bouwer L, Schinko T, Surminski S, Linnerooth-Bayer J (eds) Loss and damage from climate change. Concepts, methods and policy options. Springer, Cham, pp 39-62

Warner K, Van der Geest K (2013) Loss and damage from climate change: local-level evidence from nine vulnerable countries. Int J Global Warming 5:367. https://doi.org/10.1504/IJGW.201 3.057289

Weaver CP, Lempert RJ, Brown C, Brown C, Hall JA, Revell D, Sarewitz D (2013) Improving the contribution of climate model information to decision making: the value and demands of robust decision frameworks. Wiley Interdisc Rev: Clim Change 4:39-60. https://doi.org/10.1002/wcc. 202

Wigley TML (2005) The climate change commitment. Science 307:1766-1769. https://doi.org/1 $0.1126 /$ science. 1103934

Williams AP, Funk C (2011) A westward extension of the warm pool leads to a westward extension of the Walker circulation, drying eastern Africa. Clim Dyn 37:2417-2435. https://doi.org/10.1 007/s00382-010-0984-y

Williams AP, Funk C, Michaelsen J, Rauscher SA, Robertson I, Wils THG, Koprowski M, Eshetu Z, Loader NJ (2012) Recent summer precipitation trends in the Greater Horn of Africa and the emerging role of Indian Ocean sea surface temperature. Clim Dyn 39:2307-2328. https://doi.o $\mathrm{rg} / 10.1007 / \mathrm{s} 00382-011-1222-\mathrm{y}$

Wrathall DJ, Oliver-Smith A, Fekete A, Gencer E, Reyes ML, Sakdapolrak P (2015) Problematising loss and damage. Int J Global Warming 8:274-294

Zhang X, Wan H, Zwiers FW, Hegerl GC, Min SK (2013) Attributing intensification of precipitation extremes to human influence. Geophys Res Lett 40:5252-5257. https://doi.org/10.1002/grl.5101 
Open Access This chapter is licensed under the terms of the Creative Commons Attribution 4.0 International License (http://creativecommons.org/licenses/by/4.0/), which permits use, sharing, adaptation, distribution and reproduction in any medium or format, as long as you give appropriate credit to the original author(s) and the source, provide a link to the Creative Commons license and indicate if changes were made.

The images or other third party material in this chapter are included in the chapter's Creative Commons license, unless indicated otherwise in a credit line to the material. If material is not included in the chapter's Creative Commons license and your intended use is not permitted by statutory regulation or exceeds the permitted use, you will need to obtain permission directly from the copyright holder.

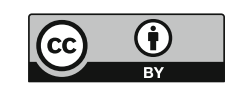

